\title{
Formal Enforcement Actions and Bank Behavior
}

\begin{abstract}
Employing a unique data set for the period 2000-2010, this paper examines the impact of formal enforcement actions targeting the core of the banks' financial safety and soundness in terms of bank capital, risk, and performance. We find that, on average, these actions reduce both the risk-weighted assets and the non-performing loans ratios of punished banks, but there is no increase in the level of regulatory capital. These effects are less powerful during the post-crisis period, suggesting that banks' scope to improve their safety and soundness condition in crisis periods is much more limited. We also find, albeit with some limitations, that the timing of formal enforcement actions is important: the more the actions are deferred relative to the continuous deterioration of the banks' financial condition, the more limited their impact on the risk-based capital ratio, while actions taken earlier help banks to improve their financial soundness.
\end{abstract}

JEL Classification: G01; G21; G28

Keywords: Formal enforcement actions; banking supervision; banks' financial condition 


\section{Introduction}

The financial turmoil that began in 2007 and led to a panic in the fall of 2008 depicted, with unparalleled force, the weaknesses of the existing financial architecture and emphasized the importance of reconsidering the current regulatory and supervisory framework, especially in the area of banking. A number of research studies (e.g., Caprio et al., 2008) emphasize the pivotal role that deficient oversight and enforcement of legally binding requirements played in establishing the conditions for the financial crisis. In a similar vein, the Basel Committee reports that appropriate enforcement actions represent an indispensable ingredient of an efficient supervisory review process under Pillar 2 of the Basel capital adequacy regime (Basel, 2006).

This paper is situated at the core of the debate regarding effective oversight and the enforcement of banking regulation. Specifically, we seek to answer two fundamental questions with direct bearing on the design of banking supervision. The first question concerns the impact that formal enforcement actions taken to address breaches of financial safety and soundness requirements (Class 1 enforcement actions) have on the banks' capital, risk, and performance. The second question focuses on the period, measured in consecutive quarters, during which the banks' risk-based capital ratios (risk-weighted assets ratios) deteriorate (increase) before the supervisor pursues Class 1 enforcement actions as a disciplinary tool ("timing of the Class 1 enforcement actions"). We then examine whether the timing of the Class 1 enforcement actions affects their corrective impact on the banks' capital and risk. Essentially, by addressing these two questions, we review and shed light on the effectiveness of supervisory intervention in the field of banking.

To perform this analysis, we construct a unique, hand-collected data set of formal enforcement actions imposed on individual US banks over the period from 2000 to 2010 . We first collect all formal actions imposed by the two federal banking agencies, namely, the Federal Deposit Insurance Corporation (FDIC) and the Office of the Comptroller of the Currency (OCC). Next, we distinguish between different classes (types) of enforcement actions that depend on their underlying rationale and relevance to financial safety and soundness. This classification is absolutely crucial, as different types of formal enforcement actions can have diverse impacts on the banks' capital, risk, and performance. Thus, we only consider data on those formal enforcement actions, the raison d' être of which concerns the core aspects of banks' financial safety and soundness, such as, capital 
adequacy and liquidity, asset quality, adequacy of provisions and reserves, large exposures, and exposures to related parties (Class 1 enforcement actions).

Our empirical strategy follows the well-established literature that examines the impact of an endogenous event on various aspects of the bank concerned. We construct and employ an instrumental variable based on the ratio of female to total bank examiners. Bank examiners are employees of the federal banking agencies who are commissioned to assess the banks' condition and adherence to laws and regulations, as well as to document their findings and conclusions in their examination reports. We demonstrate that the presence of a larger share of female bank examiners in specific states in a given year is on average more likely to produce findings and conclusions in the examination reports that lead to the imposition of formal enforcement actions on banks. This is in line with the empirical finding that the presence of female directors on corporate boards is associated with more intense board monitoring (e.g., Adams and Ferreira, 2009). Our finding is also in line with the strand of the literature inferring that female accounting auditors tend to be more risk averse (e.g., Hardies et al., 2010; Ittonen et al., 2013) and possess greater moral reasoning skills (e.g., Eynon et al., 1997; Ittonen and Vähämaa, 2012) than their male counterparts, which translate into more rigorous auditing.

A noticeable limitation of our study is that any information regarding bank examiners and by extension regarding our instrumental variable is available at the state-year level (i.e., state-quarter after 2007Q3) - not at the bank-quarter level. Though we control for an array of bank-level characteristics, this limitation, which admittedly might create some imprecision in our inference, implies that the presence of a larger share of female examiners at the state-year level positively affects the probability that the banks examined by examiners from this state will receive a Class 1 enforcement action. A residual concern with our instrumental variable is that it is only available for the FDIC and the OCC, thus leaving out the third pillar of the US bank supervision structure, i.e., the Board of Governors of the Federal Reserve System (Fed).

In essence, the baseline results indicate that the Class 1 enforcement actions encourage the punished banks to reduce their risk-weighted assets in the following year and, through this decline, improve their risk-based capital ratio. In addition to curtailing risk-taking incentives, the Class 1 enforcement actions appear to also result 
in a reduced non-performing loans ratio, albeit at the expense of the punished banks' performance profiles. With a few wrinkles, these results are robust to a number of re-specifications.

It is striking that differences in the results are observed when considering the response of banks' financial safety and soundness variables in the pre- and post-crisis periods. The decline of the risk-weighted assets and nonperforming loans ratios is less pronounced in the post-crisis period. A plausible explanation is that the adverse economic conditions during the crisis negatively affected borrowers' repayment capacity, curtailed the banks' risk-management powers and constrained opportunities for raising new capital. Thus, the corrective impact of Class 1 enforcement actions diminishes in crisis periods, as punished banks' room of maneuver in taking remedial actions to improve their safety and soundness condition is much more limited.

We also infer, albeit with some limitations introduced by the endogeneity of formal enforcement actions' timing, that bank safety and soundness is affected by the timing of the Class 1 enforcement actions. Specifically, we demonstrate that the increase in the risk-based capital ratio and the decline in the risk-weighted assets ratio as a result of the Class 1 enforcement actions by the FDIC and the OCC becomes relatively less pronounced as the number of quarters since the beginning of the deterioration of the risk-based capital ratio and of the rise in the risk-weighted assets ratio increases. Further, we find that for banks with fewer quarters of declines in their riskbased capital ratios and increases in their risk-weighted assets ratio before the Class 1 enforcement actions, the impact of such actions on these variables becomes greater one year after the event, while the returns on assets are positive and significant. Our analysis suggests that the longer the period during which the banks' risk-based capital ratios deteriorate and their risk-weighted assets ratios increase before the enactment of the Class 1 enforcement actions, the more likely it is that the punished banks face serious distress.

The contributions of our paper are threefold. First, we examine the full array of formal enforcement actions imposed on US banks by the FDIC and the OCC in the first decade of the 2000s and classify them on an individual basis according to their underlying rationale. The objective is to focus on those specific actions that are directly intended to remedy financial safety concerns, that is, Class 1 enforcement actions (see Appendix A). This important refinement serves as an indispensable cleansing mechanism for our data set and provides a distinctive opportunity to perform the analysis with a precise focus on formal enforcement actions that address violations of 
the legal requirements with a direct bearing on banks' financial safety and soundness, instead of directing our analysis to all enforcement actions.

Second, we employ the subset of the aforementioned data covering the formal enforcement actions imposed by the FDIC and the OCC to assess the responses of the punished banks with respect to several different elements of capital, risk, and performance for a period covering the subprime financial crisis. This examination provides a thorough picture of the bearing that the Class 1 enforcement actions have on the financial condition of banks. Moreover, by differentiating between the period before and after the beginning of the subprime crisis in the third quarter of 2007, we examine the heterogeneous impacts that the Class 1 enforcement actions might have in good and bad economic periods. From this perspective, our data and analysis offer distinctive depth and breadth to the empirical design and generate appealing results.

Finally, we use our data set containing the Class 1 enforcement actions imposed by the FDIC and the OCC and offer robust evidence regarding the effect that the timing of such actions has on bank safety and soundness. To this end, we focus on the actual implementation of those legal standards that pertain most closely to the banks' financial safety and soundness, instead of concentrating on supervisory ratings of banks' performance or on proxies for such ratings. We believe, therefore, that our work assesses the effectiveness of a pivotal disciplinary tool in the arsenal of banking supervisors (i.e., Class 1 enforcement actions) fairly accurately.

The remainder of the paper proceeds as follows. Section 2 provides a concise overview of the mechanics of US bank supervision, with an emphasis on formal enforcement actions, and formulates the hypotheses of our study. Section 3 presents the empirical method and explains how we construct the data set used in the present study. Section 4 analyzes the empirical findings. Section 5 concludes.

\section{The Mechanics of US Bank Supervision: An Overview}

Banking supervision in the US is assigned to multiple agencies with coinciding supervisory competences. Three federal banking agencies supervise banks, savings associations, and thrifts. In its capacity as the chartering authority, the OCC supervises national banks (federally chartered banks) and is responsible for the federal branches or agencies of foreign banks and federal savings associations. The FDIC is the appropriate federal 
banking agency for insured state banks that are not members of the Fed system, as well as for foreign banks that have an insured branch and state savings associations. The Board of Governors of the Federal Reserve System (Fed) supervises the state banks that are members of the Fed system. It also supervises bank holding companies and their subsidiaries (other than depository institutions); foreign banks with US operations but without an insured branch; foreign banks with US state-chartered branches and agencies; agencies or commercial lending companies other than federal agencies; and savings and loan holding companies and their subsidiaries (other than depository institutions). ${ }^{1}$

These three federal bank supervisors monitor safety and soundness conditions through a combination of on- and off-site surveillance programs. On-site audits constitute the cornerstone of the supervisory process. The rule is that the appropriate federal banking agency conducts a full-scope, on-site examination of each insured depository institution at least once every 12 months. A full scope, on-site examination encompasses the audit procedure necessary to evaluate all components of the Uniform Financial Institutions Ratings Systems (CAMELS rating system). The components of CAMELS are capital adequacy (C), asset quality (A), management (M), earnings (E), liquidity (L) and sensitivity to market risk (S). With the exception of the M component, which is of a qualitative nature and primarily refers to the effectiveness of internal control and audit systems, all of the elements of the CAMELS rating system have a predominantly quantitative character (e.g., Demirgüc-Kunt, 1989; De Young et al., 2001; OCC, 2007, at pp. 68-89; FDIC, 2012, at s. 1.1).

Under CAMELS, all banks are assigned a composite rating on the basis of the evaluation of these six components. Composite and component ratings are based on a one-to-five scale. A composite rating of one or two implies that any identified weaknesses are minor and can be handled routinely by the board of directors and management. A composite rating of three or four suggests a combination of moderate to severe weaknesses, as well as that the management might lack the ability or willingness to effectively addresses the deficiencies within an appropriate timeframe. A composite rating of five denotes extremely unsafe and unsound practices that result in critically deficient performance and that the volume and severity of the problems are beyond the management's

\footnotetext{
${ }^{1}$ See 12 US Code 1813.
} 
ability or willingness to control or correct. ${ }^{2}$ All of the on-site exam materials are confidential, including the CAMELS rating. The latter is only communicated to the bank's senior management and is not publicly disclosed, even on a lagged basis.

Supervisors also heavily rely on off-site monitoring systems to supplement the CAMELS ratings. All three federal banking agencies make extensive use of the quarterly Reports of Condition and Income (call reports) to remotely assess the condition of banks and schedule the timing and scope of on-site audits. The self-reported information from the banks not only forms the basis of the off-site supervisory monitoring between on-site audits but is also used to develop early-warning models intended to identify excessively risky banks in a timely manner (e.g., Cole et al., 1995).

The findings from the on-site examinations and the off-site monitoring, as well as the CAMELS ratings assigned to each bank, play an influential role in the decision to take an enforcement action. In the US banking supervision system, enforcement actions can be informal and formal. Informal enforcement actions comprise commitments, board resolutions, approved safety and soundness plans, and memoranda of understanding. Informal actions are not legally enforceable or publicly available, and they are reserved for relatively less significant types of misconduct and for banks with a composite CAMELS rating of 1 or 2, or occasionally 3 (OCC, 2007, at pp. 56-57; FDIC, 2012, at ss. 1.1, 13.1, 15.1). Formal enforcement actions, by contrast, are statutorily authorized or mandated, are legally enforceable, and are publicly disclosed. Formal actions are considered when informal actions prove inadequate or ineffective; when a bank receives a composite CAMELS rating of 4 or 5 , or occasionally 3 ; or where the severity of the misconduct calls for a less cooperative and more drastic, definite, and direct supervisory intervention to constrain the bank management's room to maneuver (OCC, 2007, at pp. 56-57; FDIC, 2012, at ss. 1.1, 13.1, 15.1). The most prevalent formal enforcement actions include cease and desist orders; written agreements; suspension, removal, and prohibition orders; civil money penalties; prompt corrective action directives; safety and soundness orders; and capital directives.

\footnotetext{
${ }^{2}$ See OCC (2007), at pp. 56-57; FDIC (2012), at s. 1.1.
} 
It follows that supervisors enjoy broad discretion in applying informal or formal actions depending on a case-by-case basis assessment of the bank's overall condition, the nature and severity of the problems encountered and the bank management's commitment and ability to address the identified problems (OCC, 2011, at p. 7). Informal actions typically constitute the first resort of supervisors in providing guidance to a bank and soliciting the board's commitment to correct identified problems before they affect the bank's condition (OCC, 2007, at pp. 46-47). As such, informal actions play a key role in incentivizing banks to promptly correct identified deficiencies. Formal enforcement actions occupy an equally prominent position in the supervisory arsenal (GAO, 1991; Curry, 1997). As noted above, formal enforcement actions are used when informal actions are inadequate or ineffective in influencing bank management to correct identified problems. Moreover, formal actions may well be imposed regardless of the bank's composite CAMELS rating and irrespective of the completion of the examiners' report and the application of informal actions. This would be the case when the bank experiences significant problems or weaknesses in its systems and controls; serious insider abuse; substantial violations of law or serious compliance problems; or a failure to maintain satisfactory books and records or provide examiner access to books and records, and as a result, the supervisor is unable to determine the bank's true financial condition (GAO, 1991, at pp. 17-18; OCC, 2011, at pp. 4-9; FDIC, 2012, at ss. 1.1, 14.1). Therefore, formal enforcement actions not only constitute the second and strongest line of defense against identified deficiencies that have not been promptly corrected following the release of an informal action but may also be the appropriate initial action based on the rating of the bank and the severity of the problem (OCC, 2011, at p. 8; FDIC, 2012, at ss. 1.1, 14.1).

We examine the underlying rationale of formal enforcement actions to identify those with the most direct relevance to and bearing on banks' financial safety and soundness (Class 1 enforcement actions). We then examine the effect of these Class 1 enforcement actions on the banks' behavior. The expectation is that the Class 1 enforcement actions will constrain the banks' incentives to undertake activities posing safety and soundness concerns through at least three basic channels. First, the Class 1 enforcement actions signal adverse information regarding the targeted bank's condition that is private to the supervisors. As a result, these actions are likely to enhance market discipline and curtail the appetite for risk-taking (e.g., Brous and Leggett, 1996; Slovin et al., 1999; Jordan et al., 2000). Second, the Class 1 enforcement actions can impose direct costs on the bank's 
management (e.g., the limitation of management decision-making powers, increase of supervisory scrutiny, diversion of scarce management time, and loss of reputation) that also constrain excessive risk-taking (e.g., Brous and Leggett, 1996; Slovin et al., 1999; Milne, 2002). Third, the Class 1 enforcement actions, as opposed to informal actions, are judicially enforceable in court, and noncompliance carries serious penalties, which in turn increases the likelihood that such actions will generate behavioral changes (GAO, 1991; Curry, 1997).

The first objective of this paper is to examine the impact of Class 1 enforcement actions on banks' capital, risk, and performance. From this perspective, our research is related to a somewhat limited strand of literature that assesses the relationship between enforcement actions and bank behavior. Peek and Rosengren (1995) find that enforcement actions imposed on New England banks result in the reduction of loan portfolios and bank lending. Curry (1997) finds that formal enforcement actions lead troubled banks to more pronounced declines in asset growth, dividend rates and external capital infusions, while Curry et al. (1999) move one step further and report that formal enforcement actions have a more significant impact on areas over which the bank's management has a high degree of control, as opposed to areas in which external factors are more influential. Delis and Staikouras (2011) construct a panel data set using country-level information on the annual number of on-site audits and enforcement actions for 17 countries over the period 1998-2008 and infer a linear and negative relationship between enforcement actions and bank risk. More recently, Berger et al. (2012) examine the impact of regulatory interventions taken by the Federal Financial Supervisory Authority in Germany against banks for the period 19992009 and find a statistically and economically significant reduction in both risk-taking and liquidity creation.

The impact of Class 1enforcement actions on bank fundamentals can vary significantly depending on the state of the economy. The corrective effect of Class 1 enforcement actions is potentially amplified during stable economic periods, where troubled banks can raise new capital and/or extract liquidity relatively easier and from a wider array of sources. Further, in stable economic periods, the banks' borrowers are less likely to default on their loans, while the secondary markets for loans are liquid thus allowing the punished banks to more easily adjust their portfolios without significant losses. In contrast, the corrective effect of Class 1 enforcement actions during crisis periods might be less potent. This is so, because the scarcity of capital and the draining of liquidity as well as the disruption of the secondary markets for loans and the deterioration of credit quality as a result of an 
economy-wide crisis are likely to place significant constraints on the punished banks' scope to take remedial actions in order to improve their safety and soundness condition.

The second objective of our paper is to assess whether the period (i.e., consecutive quarters) during which the banks' risk-based capital ratios (risk-weighted assets ratios) deteriorate (increases) before the application of Class 1 enforcement actions (timing) affects the impact of such actions on the banks' capital and risk. As colorfully stated in a Report of the US General Accounting Office, "[t]here is a point in the regulatory process where more forceful actions need to be brought into play", otherwise "underlying problems can become intractable" (GAO, 1991, at p. 7). We expect, therefore, that Class 1 enforcement actions have a varied disciplinary impact on bank behavior, depending on their timing. This could be the case because earlier application of Class 1 enforcement actions relative to the development of the banks' safety and soundness problems ensures that the condition of ailing banks does not deteriorate and allows detected weaknesses to be efficiently addressed. Moreover, precisely because Class 1 enforcement actions impose costs on suffering - but not yet failing - banks, the latter are encouraged to align their behavior with the preferences of supervisors, and simultaneously, the cost of engaging in unsafe practices increases for all banks. By contrast, relatively late application of Class 1 enforcement actions may undermine the effectiveness of the law and could generate perverse incentives: the more a bank's safety and soundness problems are allowed to grow before Class 1 enforcement actions are used, the less that specific bank has to lose from assuming greater risk, and the more tempting divergence from prudent risk-taking behavior becomes for all banks (e.g., GAO, 1991; Galloway et al., 1997; Milne 2002).

In light of the preceding discussion, the questions that this paper aims to answer are formulated as follows:

Q1a: What is the impact of Class 1 enforcement actions on the banks' capital, risk, and performance?

Q1b: Does the impact of Class 1 enforcement actions on the banks' capital, risk, and performance differ between the pre- and post-crisis periods?

Q2: Does the timing of Class 1 enforcement actions affect the disciplinary impact of such actions on the banks' capital and risk? 


\section{Data and Empirical Identification}

\subsection{Empirical Design}

We begin with an unbalanced panel data set for all US banks supervised by the FDIC and the OCC, including those that were subject to a formal enforcement action (punished or treated banks) and those were not (nonpunished or non-treated banks). Because we use a $(-4,+4)$ quarter window around the enactment of a formal enforcement action in our analysis, we use accounting data for the period from 1999Q1 to 2011Q4, that is, an extension of our 2000Q1 to 2010Q4 panel by one year at each end.

Our objective is to estimate the effect of formal enforcement actions on the capital, risk and performance of punished banks, while accounting for the underlying endogeneity. This endogeneity arises from the fact that we do not observe how the punished banks might have behaved had they not been subject to a formal enforcement action. In this framework, least-squares-based methods are biased and inconsistent.

Thus, we use a two-stage instrumental variables (IV) treatment effects model of the form

$$
s_{i t}=b_{0}+b_{1} z_{i t}+b_{2}\left(x_{i, t}-x_{i, t-4}\right)+e_{i t}
$$

and

$$
y_{i, t+4}-y_{i, t}=a_{0}+a_{1}\left(y_{i, t}-y_{i, t-4}\right)+a_{2} \widehat{s_{l t}}+a_{3}\left(x_{i, t}-x_{i, t-4}\right)+u_{i t}
$$

Equation (1) is typically referred to as the treatment equation. In this equation, $s$ takes the value of one for banks subject to a formal enforcement action at quarter $t$ (i.e., the quarter within which the enforcement action is signed and essentially becomes effective) and zero otherwise. Equation (2) is the response equation. Here, the dependent variable is the year-on-year change in the number of bank characteristics $y$ pertaining to capital, risk, and performance.

We examine the response of the bank characteristics in the time window of four quarters after the event of the formal enforcement action. Essentially, the system of equations (1) and (2) models the response of a vector of the punished banks' characteristics relative to those of non-punished ones, which serve as the control group. The coefficient of interest is $a_{2}$, which measures the average treatment effect by capturing the difference in the one- 
year change in the response variable for banks that are subject to a formal enforcement action relative to nonpunished banks. Formally, $a_{2}$ equals $\left(\mathrm{E}\left[y_{\mathrm{t}+4}^{\mathrm{T}}\right]-\mathrm{E}\left[y_{\mathrm{t}}^{\mathrm{T}}\right]\right)-\left(\mathrm{E}\left[y_{\mathrm{t}+4}^{\mathrm{C}}\right]-\mathrm{E}\left[y_{\mathrm{t}}^{\mathrm{C}}\right]\right)$, where $\mathrm{T}$ denotes the punished banks and $\mathrm{C}$ the control group. This is equivalent to $\left(\mathrm{E}\left[y_{\mathrm{t}+4}^{\mathrm{T}}\right]-\mathrm{E}\left[y_{\mathrm{t}+4}{ }^{\mathrm{C}}\right]\right)-\left(\mathrm{E}\left[y_{\mathrm{t}}^{\mathrm{T}}\right]-\mathrm{E}\left[y_{\mathrm{t}}^{\mathrm{C}}\right]\right)$, that is, the difference-indifferences estimate of the impact of being subject to a formal enforcement action.

We also include the annual lag of the dependent variable in equation (2) to account for the possible differences in the trend of the response variable between the treated and control groups before the treatment that might introduce bias in the estimation of $a_{2}$. In turn, $x$ is a vector of the bank-level variables that relate to the condition of the banks' balance sheets. These variables affect the probability of being subject to a formal enforcement action in equation (1), while they also act as control variables for the response variables $y$ in equation (2). ${ }^{3}$ The main consideration here is that a bank's condition in the quarters before a formal enforcement action is the main mechanism through which a problem bank is identified. ${ }^{4}$ Thus, $x$ should comprise variables that characterize bank health and performance. Finally, $z$ is a variable that affects the probability of imposing a formal enforcement action on a bank and is related to the behavior of the supervisors, although the vector does not directly affect the response variables $y$.

We simultaneously estimate equations (1) and (2), where equation (1) is a probit model and equation (2) is a linear regression. We assume that the error terms from equations (1) and (2) are jointly normally distributed.

\footnotetext{
${ }^{3}$ Note that in the treatment-effect models, we do not need to include the same set of control variables in the first and second stages of the regressions (as is the case, for example, in, the two-stage least squares regression). Nevertheless, here we chose to include the same variables for identification purposes, i.e., in the first stage, we also use the variables that characterize the banks' health.

${ }^{4}$ The choice of the covariates $x$ also plays an important role in capturing the sources leading to differential time trends for the response variable $y$ between the treated and non-treated banks prior to the treatment. As Lechner (2011) suggests, using pretreatment (lagged) measurements as we do in equation (2) is the best empirical strategy to satisfy the parallel trends assumption for the pre-treatment period.
} 
This system is estimated using the two-step consistent estimator of the parameters. ${ }^{5}$ We provide definitions for all of the variables used in our study in Table I and summary statistics in Table II. In the remainder of this section, we discuss these variables following the presentation of our data set of formal enforcement actions.

[Insert Tables I and II about here]

\subsection{Formal Enforcement Actions}

We begin with the data on all of the formal enforcement actions by the two federal banking agencies (FDIC, OCC) against banks in the period from 2000Q1 to 2010Q4 in the US. This is a new, hand-collected data set with a total number of 2,458 formal enforcement actions of all classes. We do not include formal enforcement actions by the Fed in our sample because we lack an appropriate instrumental variable for this supervisory agency. We also exclude from the sample those supervisory decisions that do not contain some type of reprimand for violations of the law and/or regulations (e.g., modification or termination of prohibition orders, denial of acquisition of control, voluntary termination of insurance, interlocutory reviews, termination of cease and desist orders, etc.).

We derive information on the formal enforcement actions of the FDIC and OCC banking supervisory authorities' websites, and we assess these actions' underlying rationale on a case-by-case basis. We divide the formal enforcement actions into four different classes on the basis of their raison d'être and their relevance to the financial safety and soundness of the banks (see Appendix A). Thus, we are able to detect and focus our analysis on the Class 1 enforcement actions that are directly intended to address these concerns vis-à-vis the actions of the other classes that are indirectly or remotely related to financial safety and soundness.

In the next step, we match the name, city, and state of each bank exposed to formal enforcement actions with the relevant accounting data from the bank call reports (FFIEC 031/041 Call Reports). If any discrepancy exists between the information contained in the supervisory decision that sets out the formal enforcement action

\footnotetext{
${ }^{5}$ We can also estimate the first stage using the conventional maximum likelihood technique, but for some of the response variables, the initial values are not feasible, while the underlying assumptions of asymptotic theory are stronger. For those response variables for which the models converge, the results are equivalent to the two-step consistent estimates.
} 
and that contained in the call reports, then we manually check the information characteristics of each of these banks by visiting the institutions' search form of the National Information Center provided by the FFIEC. In the event of any remaining discrepancies concerning the identity of the bank under consideration, we drop the relevant observation from the sample.

Because the call report data are available on a quarterly basis, we match the date that the formal enforcement action becomes effective (i.e., it is signed) with the relevant quarter. For example, all of the enforcement actions that become effective from January 1 to March 31 are matched with the first quarter of that year. Because a number of formal enforcement actions of Class 1 or different classes are imposed on the same bank within the $(-4,+4)$ quarter frame around the event, we choose to use only those Class 1 enforcement actions with a clean $(-4,+4)$ quarter event window, provided that the financial account data are available for this event window. This choice allows for the examination of the impact of the event on the bank characteristics free of other concurrent formal enforcement actions. In conclusion, our working sample includes 859 Class 1 enforcement actions imposed by the FDIC and the OCC in the 2000Q1-2010Q4 period.

Table III provides the descriptive statistics per year for (1) the number of formal enforcement actions by the FDIC and the OCC per class (Panel A), (2) the number of Class 1 enforcement actions for each of the two (FDIC, OCC) federal banking supervisors (Panel B), and (3) the number of Class 1 enforcement actions with a clean $(-4,+4)$ event window for the FDIC and the OCC (Panel C). As the figures in Panel A show, Class 1 enforcement actions constitute the largest group (approximately $43 \%$ of the total), whereas Class 2 enforcement actions constitute the smallest group. Additionally, the total number of enforcement actions rises sharply after 2008, primarily due to the increase in Class 1 enforcement actions (Panel B), which indicates the heavy toll that the financial crisis took on banks.

[Insert Table III about here]

\subsection{Response Variables}

We use a number of response variables $y$ to characterize the capital, risk, and performance of the banks. As equation (2) indicates, these variables are in differences over the time frame $t$ to $t+4$. They comprise two sets: the first contains ratios, and the second contains variables in logs (levels). Because we use a number of different 
response variables to measure the capital, risk, and performance of banks, some of these variables are also included as control variables. For example, we use our capital variable as a control in the risk equation and vice versa.

In the top graphs of Figure I, we present the fluctuations in the means in some of our response variables for the punished banks in the eight quarters before and after the imposition of the Class 1 enforcement actions, along with the fluctuations in the respective medians for all of the banks in our sample. $t=0$ is the quarter that the enforcement action becomes effective (i.e. it is signed). In the bottom graphs, we present the equivalent fluctuations of the cross-sectional standard deviation, i.e., the cross-sectional dispersion around the mean, in these response variables for the punished banks. A stable across time cross-sectional standard deviation of a response variable is the outcome of parallel trends of this variable across punished banks and indicates a similar bank behavior in the cross section. A declining standard deviation suggests a convergence towards the mean and an increasing standard deviation suggests a divergence from the mean. Additionally, Figures II and III present the respective fluctuations in the periods before and after the onset of the subprime crisis (the cutoff point is 2007Q3). We expect that these figures provide an initial indication of changes in our response variables before and after the enactment of the Class 1 enforcement actions.

\section{[Insert Figures I, II, and III about here]}

The variable used to gauge the banks' capital adequacy is the risk-based capital ratio. This ratio is the most widely used by supervisors to assess a bank's capital adequacy. A higher value reflects a higher degree of capital adequacy and a lower probability of insolvency. We note in Table II and Figure I that the punished banks have, at the time of the Class 1 enforcement action, significantly lower risk-based capital ratios compared to the full sample of banks (see Panels B and A of Table II, respectively).

Figure I indicates that the total risk-based capital ratio declines before the enactment of the Class 1 enforcement action and begins increasing approximately two quarters before the enactment. This reverse of the declining trend in the capital ratio could be a response to the supervisory pressure exerted on banks either through informal enforcement actions or through other unofficial communications with and guidance provided to bank management in the course of bank examinations that led to the decision to issue a formal enforcement action 
(Curry, 1997; Brunmeier and Willardson, 2006). Most important, after the enactment of the Class 1 enforcement action, the risk-based capital ratio increases rapidly. However, as Figures II and III indicate, this increase only places the punished banks above the cross-sectional median during the pre-crisis period, when, apparently, it is easier to raise new capital. The bottom graphs in Figures II and III, depicting the standard deviations for the preand post-crisis period, respectively, indicate that there is a peak in the cross-sectional volatility of the risk-based capital ratio of punished banks one year after the enactment of a Class 1 enforcement action. In both the pre- and post-crisis periods, the cross-sectional volatility of the risk-based capital ratio is somewhat amplified before the application of Class 1 enforcement actions, yet it is considerably smaller than the increase following such actions. Much like the respective standard deviations in Figure I, these patterns reflect the similar behavior of punished banks before the enactment of Class 1 enforcement actions with respect to their risk-based capital ratios and the diverse impacts these enforcement actions have on the banks' capital adequacy after the event.

We also use the ratio of risk-weighted assets to total assets (risk-weighted assets ratio) and the ratio of liquid assets to total assets (liquidity ratio). The first is an indicator of credit risk, especially as perceived by supervisors: a higher value indicates a more risky bank portfolio. The second is the primary indicator of liquidity risk: a higher value indicates lower liquidity risk. According to the summary statistics, the punished banks have higher risk-weighted assets and liquidity ratios relative to the sample average. Figures I to III indicate that the punished banks have a substantially higher risk-weighted assets ratio relative to the respective median for all of the banks in our sample for at least two years before the enactment of a Class 1 enforcement action. Interestingly, the cross-sectional standard deviation of this variable for the punished banks reaches its minimum level at the time when the Class 1 enforcement action is imposed. This is especially true for the post-crisis period (see Figures I and III). Thus, the expectation of the effect of the Class 1 enforcement action completely maps alterations in the cross-sectional volatility of the risk-weighted assets ratio, which is one of the most important ratios under supervisory scrutiny. 
Another commonly used measure of credit risk is the non-performing to total loans ratio (non-performing loans ratio), which provides an ex-post portrayal of the credit risk of a bank's loan portfolio. ${ }^{6}$ As Figures I to III show, the average non-performing loans ratio is higher for the punished banks and tends to stabilize in the year after the enactment of a Class 1 enforcement action. However, there appears to be a marginal decline in nonperforming loans within one year after the enactment of a Class 1 enforcement action, primarily in the period before the subprime crisis. The cross-sectional volatility in this measure also begins to decline approximately one year after the enactment of a Class 1 enforcement action.

The impact of the Class 1 enforcement actions on the banks' risk-related performance is captured by the ratio of the total profits before tax to total assets (ROA). We complement this basic ratio with the standard deviation of the banks' profits $(\sigma \mathrm{ROA})$. $\sigma \mathrm{ROA}$ is calculated using a rolling 12-quarter window; it reflects both the performance and the riskiness of the bank and is used quite frequently in the related banking literature (e.g., Demirgüç-Kunt et al., 2008). Unsurprisingly, $\sigma \mathrm{ROA}$ is markedly higher for the punished banks compared to the sample average (0.009 and 0.005, respectively), as Table II indicates.

The variables in logs (levels) are intended to identify the separate effect of the Class 1 enforcement actions on capital, risk, and lending. To this end, we use the natural logarithm of the risk-based capital and the risk-weighted assets. We further decompose the risk-weighted assets into three categories, namely, very risky assets (those with a 100\% risk weight), medium-risk assets (those with a 50\% risk weight), and low-risk assets (those with a $20 \%$ risk weight). To examine the impact of Class 1 enforcement actions on overall lending activity, we use the natural logarithm of total loans.

\subsection{Instrumental and Control Variables}

\footnotetext{
${ }^{6}$ Initially, we also employed two additional ratios to proxy credit risk, namely, information on the 30-89 day delinquencies and the 90+ day delinquencies. The results obtained using these two variables are equivalent to those obtained using the nonperforming loans ratio and, thus, are not reported here to avoid repetition.
} 
The variable $z$ in equation (1) is crucial for identifying the probability of being subject to a formal enforcement action and should validate the exclusion restriction. Ideally, we need an instrumental variable that satisfies the exclusion restriction and is observed at the bank-quarter level (e.g., by using information pertaining to supervisory agencies' characteristics). To this end, we consider that focusing on the characteristics of bank examiners constitutes an appealing option. However, we lack information on these characteristics for each bank over time. We thus resort to information available on the characteristics of bank examiners at the state-year level (i.e., statequarter after 2007Q3), which admittedly might introduce some imprecision in our inference.

Specifically, we use the FedScope Employment Cube data, which are available online from the Office of Personnel Management. This database includes information such as the salary, length of service, age (these three are provided on a group basis), occupation, official duty station (i.e., state), and gender of the bank examiners on a yearly basis (quarterly from 2007Q3 onwards). From these data, we transform the gender variable into a dummy variable equal to one for female and zero for male bank examiners. Then, we calculate an average gender variable, i.e., the ratio of female to the total number of the bank examiners for each supervisor per state and year (quarter where available) for the FDIC and the OCC. We term this variable as Original Gender of Supervisor's Bank Examiners.

We further refine this instrumental variable to account for potential trends in the relative growth of female bank examiners and to ensure that this variable contains information beyond the social-economic characteristics of the states that might affect our outcome variables. As shown in Figure A.I. in Appendix A, the share of female bank examiners exhibited a slight increase for both the FDIC and OCC, especially after 2005 and up to circa 2010. We remove the time trend in the Original Gender of Supervisor's Bank Examiners and the socio-economic and demographic characteristics of the states for each supervisor separately by employing a fixed effects model with states as the cross-sectional identifiers and a time trend for the period 2000Q1 to 2009Q1. The results of these regressions are reported in Table A.II of Appendix A. The error component from each of these two regressions is employed as an instrument (named Gender of Supervisor's Bank Examiners) for the respective supervisory agency. Information on the matching of our instrumental variable to the banks in our sample is provided in Appendix B. 
Our choice to run the pre-first stage regression to obtain the instrument employed in our analysis, is in principle, equivalent to using the Original Gender of Supervisor's Bank Examiners as instrument and including state fixed effects and the time trend in equations (1) and (2). However, the latter approach is more cumbersome for two reasons. First, adding the state fixed effects in equation (1) prevents a number of regressions from calculating standard errors, a problem occurring from the inclusion of the state fixed effects in equation (1). ${ }^{7}$ Second, when this model does give results, ${ }^{8}$ the state fixed effects in equation (1) are jointly statistically insignificant. This implies that there are 51 statistically insignificant state dummy variables in equation (1) that over-identify the model. In contrast, the state fixed effects in the pre-first stage regression are jointly significant, thus ensuring the cleansing of our instrument Gender of Supervisor's Bank Examiners from state characteristics, the presence of which may violate the exclusion restriction.

The economic intuition behind our choice to run the pre-first stage regression is that the state characteristics do not affect the probability of banks being punished, but do affect the Original Gender of Supervisor's Bank Examiners in the pre-first stage model. Thus, our approach involving the pre-first stage regression seems to be a suitable alternative to a standard two-stage treatment effects model, which leads to estimation problems in several of our regressions, despite the limitation of adding one more stochastic disturbance from the pre-first stage regression.

We posit that the Gender of Supervisor's Bank Examiners satisfies the exclusion restriction by exclusively affecting the business model of banks through the supervisory process. Empirical evidence in the field of corporate governance and financial auditing demonstrates that gender differences in risk tolerance, screening diligence and moral reasoning abilities may affect the quality of board monitoring and auditing, in the sense that the presence of female directors on corporate boards and female accountants in the auditing process tends to be associated with more rigorous board monitoring and auditing, respectively. For these reasons, we expect that

\footnotetext{
${ }^{7}$ This is not a problem with our approach that includes the state fixed effects in the pre-first stage model of the Original Gender of Supervisor's Bank Examiners.

${ }^{8}$ These results are in most cases qualitatively similar to the ones reported in our paper.
} 
higher female participation in the bank examination process will yield more formal enforcement actions. In contrast, there is no reason to expect that the share of female bank examiners will have a direct impact on banks' business models if not through the supervisory process, especially after extracting the state fixed effects and the time trend of the original variable.

We postulate that our instrument satisfies two further assumptions. First, supervisors do not display bias concerning the hiring of candidate bank examiners or the assignment of auditing work to already employed bank examiners (FDIC, 2005; OCC, 2007). Second, we note a small cross-sectional difference in the levels of female bank examiners between the FDIC and the OCC. To account for this and potentially other differences in supervisory policy between the two supervisors, as well as between the business models of banks supervised by the OCC and the FDIC, we include a dummy variable in both equations (1) and (2) that takes value one if the bank is supervised by the FDIC and zero if the bank is supervised by the OCC. A potential limitation of our instrumental variable is that it is observed at the state-year level (state-quarter after 2007Q3), while the formal enforcement actions are observed at the bank-quarter level. As a result, our instrumental variable could capture artificial correlations for clusters of banks within states. To address this concern, the role of the remaining control variables in the first stage is crucial. ${ }^{9}$

Tables A.III and A.IV in the Appendix A provide more quantitative information about the approach and the instrument used. The former Table reports descriptive statistics for the yearly averages of the Original Gender of Supervisor's Bank Examiners per state for the FDIC and the OCC separately. The latter reports descriptive statistics for socioeconomic variables at the state-year level in Panel A and correlations between the state socioeconomic and bank variables, as well as between the Original Gender of Supervisor's Bank Examiners and the instrument variable in Panel B.

Based on the discussion in section 2 regarding the CAMELS rating system, we also include as control variables in both stages of the model a number of bank characteristics $x$. The importance of including these

\footnotetext{
${ }^{9}$ To further ensure that our instrumental variable is appropriate, we conduct an empirical analysis at the state-year level and find that our main results are qualitatively very similar. These results are available on request.
} 
variables in both equations (1) and (2) is guided by the fact that supervisors use measures of bank safety and soundness to construct their CAMELS ratings, and, in turn, these ratings direct supervisory attention and efforts and play an influential role in the decision to take a formal enforcement action against banks at $t$. These control variables enter the model in differences from $t-4$ to $t$ to reflect the modeling of our response variables and to account for the fact that supervisors are primarily interested in immense adverse fluctuations in the banks' safety and soundness (Grier, 2007).

We lack data on the CAMELS ratings because of their confidential character, and as a result, we use the solution proposed in the related literature (e.g., Berger et al., 2000 and 2001). Therefore, we rely on a number of financial characteristics to represent the condition of the banks with respect to capital adequacy, asset quality, earnings quality, liquidity, and sensitivity to market risk. ${ }^{10}$ We provide the precise definitions for these variables in Table I. Some of these variables have already been discussed above as response variables. For example, our measure of capital adequacy (i.e., the risk-based capital ratio) enters the equations of all of the response variables. Thus, to avoid repetition, here, we only discuss the remaining control variables.

Credit risk is the main focus of the asset-quality analysis. Therefore, we further control for the asset quality of the banks by relying on the ratio of the 90-day delinquent loans to total loans, in addition to the ratio of non-performing loans to total loans. Similar to the latter ratio, the higher the delinquent loans ratio is, the lower the quality of the bank's loan portfolio. Unsurprisingly, the punished banks have, on average, higher values of this ratio (see Table II).

We also use the ratio of non-interest income to total income, which serves as a measure of the bank's specialization and divergence from traditional banking activities. Moreover, the ratio of available-for-sale

\footnotetext{
${ }^{10}$ The list of variables that can be used as proxies for the financial component of the CAMELS rating is non-exhaustive. We experimented with a long list of alternatives. We ensure that the variables considered do not capture the same aspect of CAMELS components and are not collinear. Adding to or removing from the list any variables provided here does not have a significant impact on our main results.
} 
securities to total assets accounts for banks' exposure to market risk. We also control for the size of the bank by using the logarithm of total assets.

In addition to these bank characteristics, we use three variables common to all banks that account for the macroeconomic environment. These are the real GDP growth rate, the federal funds rate, and the financial stress index.

\section{Empirical Results}

\subsection{Responses to the Class 1 Enforcement Actions: Baseline Results}

We begin with the overall impact of the Class 1 enforcement actions on the response variables discussed in Section 3.3. Table IV reports the results. For expositional brevity, we do not report the first-stage results for all of our control variables. The results from equation (1) predict that larger, well-capitalized banks with a lower level of risk-weighted assets, non-performing loans, and volatility in the ROA are less likely to be subject to Class 1 enforcement actions. These results are relatively consistent across all of the regressions in Table IV, irrespective of the slight differences in the number of observations for the response variables and other sensitivity analyses.

[Insert Table IV about here]

Turning to the instrumental variable, Gender of Supervisor's Bank Examiners is always highly significant at the $1 \%$ level with a positive sign. This finding is intuitive and in line with the theoretical discussion in Section 3.4. Thus, we find that the probability of imposing a Class 1 enforcement action is positively associated with the presence of a higher share of female examiners by state-year (i.e., state-quarter after 2007Q3) in the two supervisory agencies (FDIC, OCC). This finding holds irrespective of the increasing number of female examiners and other state-specific characteristics, which were controlled for when we constructed our instrumental variable (see the regressions reported in Table A.II of Appendix A and the discussion in Section 3.4).

In Column I of Table IV, we report that the dummy variable for the Class 1 enforcement actions has a positive and statistically significant effect on the risk-based capital ratio in the year after the actions. Specifically, our measure of capital adequacy increases by 0.067 points, which reflects an improvement in the punished bank's regulatory capital ratio. In contrast, the risk-weighted assets ratio falls by approximately 0.032 points, as reported 
in Column II. Taken together, these results suggest that during the year following a Class 1 enforcement action, banks attempt to manage their regulatory capital ratio by radically reducing the denominator: banks constrain their risk-weighted assets through portfolio shrinkage, asset restructuring, and most notably, write-offs, while they face difficulty in raising new capital. This is confirmed (in Table V) below when we perform the analysis with the variables in levels.

The performance-related variables indicate that the Class 1 enforcement actions have a mixed effect. The impact on the banks' profitability is statistically insignificant. In contrast, there is a positive and significant effect of enforcement actions on $\sigma \mathrm{ROA}$. The average $\sigma \mathrm{ROA}$ for the banks subject to a Class 1 enforcement action in the quarter of the action is approximately 0.009 . In the year following the event, the volatility of profits increases by a further 0.009 . The continuing increase in the volatility of profits, coupled with the capital-raising difficulties of the punished banks, could also indicate a relatively amplified probability of default in the year following a Class 1 enforcement action, considering that profits, profits' volatility and capital constitute the most important indicators of bank solvency. In section 4.4 (Table XI), we assess more directly the impact of Class 1 enforcement actions on the probability of the liquidation or failure of punished banks.

In turn, the non-performing loans ratio (Column V) declines after a Class 1 enforcement action. The ratio averages at 0.054 for the punished banks in the quarter of the Class 1 enforcement action and decreases by approximately 0.018 points one year after the event. This is, perhaps, the most welcome effect of the Class 1 enforcement actions on bank behavior. Further, the liquidity ratio increases by 0.024 points (see Column VI) compared to the average of 0.074 for the punished banks - a finding that might be associated with the reduction in risk-weighted assets.

Overall, and in response to Question 1a, we infer from our baseline results that the Class 1 enforcement actions have a significant impact on the areas over which the bank's management has a high degree of control (i.e., curtailment of the risk-weighted assets ratio) vis-à-vis areas in which external factors, such as general macroeconomic conditions, play a greater role (i.e., external capital injection). Thus, the Class 1 enforcement actions result in a drastic contraction on the asset side of the balance sheet and, as a consequence, they constrain the punished banks' risk-taking incentives. Our results regarding the impact of the Class 1 enforcement actions on 
the performance and credit risk variables are rather mixed; hence prudence dictates avoiding drawing any definite policy inferences. Nonetheless, tentatively speaking, certain signs might exist - primarily derived from the areas of non-performing loans - indicating that the punished banks begin displaying signs of improvement in their risk profiles.

In Table V, the results from equation (1) are similar to those reported in Table IV. We find that risk-based capital (Column I) remains unchanged and that risk-weighted assets (Column II) decline. This finding confirms the inability of the punished banks to raise new capital. Moreover, in Columns III to V of Table V, we show that the decrease in the risk-weighted assets is due to the $20 \%$ class of risk-weighted assets ("high credit quality assets", including securities issued or guaranteed by the US Government) and the $100 \%$ category of risk-weighted assets ("high risk loans", including non-qualifying loans, consumer and commercial loans); by contrast, exposure to assets belonging to the $50 \%$ risk-weight class ("prudently underwritten loans", including qualifying mortgage and residential construction loans) rises. The overall lending of banks decreases but not in a statistically significant manner, as shown in Column VI. Therefore, the punished banks appear to primarily restructure their loan-extension policy: they adjust it to reduce credit risk and cleanse the accrued problem loans.

This overall shift towards less risky assets is consistent with the comment of Berger et al. (1995) that the prompt corrective action feature of FDICIA incites banks to substitute from the highest-risk weighted assets to the relatively lower risk-weighted assets. Indeed, the punished banks' inclination towards the $50 \%$ risk-weighted assets could be interpreted as evidence of a radical reshuffle of the asset portfolio in order to achieve a more balanced risk/reward profile that would satisfy supervisors' mandates, on the one hand, while preserving the banks' role in credit allocation, on the other hand. More specifically, punished banks seem to re-orient their business strategy along three basic lines: first, they draw liquidity by constraining their exposure to the easily realizable assets of the $20 \%$ risk-weight class; second, they moderate their risk profile and release extra resources, by contracting their position in high risk loans; and third, they tighten and improve their lending standards which is a rather common supervisory mandate contained in Class 1 enforcement actions - and direct their liquidity and credit activity towards prudently underwritten loans, which offer a more sensible risk/reward profile. 
This rebalancing of the asset portfolio allows the punished banks to smoothly recover from their financial safety and soundness problems and, at the same time, to support their financial intermediation value.

$$
\text { [Insert Table V about here] }
$$

\subsection{Responses to the Class 1 Enforcement Actions: The Effect of the Subprime Crisis}

To infer whether the impact of Class 1 enforcement actions differs between the pre- and post-crisis periods (Question 1b), we repeat the analysis reported in Tables IV and V by additionally including an interaction term between Enforcement Action and a dummy variable (named Crisis Dummy), which takes the value one for the period after 2007Q2 and zero otherwise. For expositional brevity, we only report the results for the coefficients on the enforcement action variable, the Crisis Dummy, and their interaction term.

[Insert Table VI about here]

There are important differences in the responses of the bank characteristics between the two periods. First, the increase in the risk-based capital ratio is considerably lower in the post-crisis period (the interaction effect equals -0.023 points). This result originates from both the adverse effect of the crisis on the level of riskbased capital (see Columns I and VII) and the fact that the reduction in the risk-weighted assets ratio is considerably lower in the post-crisis period (see Columns II and VIII). In this respect, the punished banks appear able to access capital during good economic periods, while the opposite holds in periods of economic decline. This latter finding indicates that the punished banks face severe difficulties in raising new capital precisely when it is most needed.

Another notable set of differences between the two sub-periods is the impact of Class 1 enforcement actions on non-performing loans. The negative effect of such actions on the non-performing loans ratio identified in the full sample appears to be offset during the post-crisis period (Column V). This finding could be associated with the deterioration in the banks' ability to write-off non-performing loans after the onset of the crisis at the same pace as they had during the pre-crisis period. The differential results on non-performing loans and on capital and risk-weighted assets in the post-crisis period explain the negative effect of Class 1 enforcement actions on ROA that is identified only in the post-crisis period (Column III). 
Overall, our results offer a positive response to Question 1b. The findings suggest that, in the post-crisis period, the latitude of the punished banks' management is severely constrained, especially in areas that are beyond the bank management's direct control (e.g., in raising new capital and managing problem loans).

\subsection{Class 1 Enforcement Actions: Sensitivity Analysis}

In Table VII, we report the results of two further robustness checks based on the estimation of equations (1) and (2). Panel A replicates the analysis reported in Table IV, when we additionally include interaction terms between Enforcement Action and a dummy variable (named Large Bank Dummy) that takes the value one for very large banks and zero otherwise. Again, we only report results for the coefficients on the enforcement action variable, the Large Bank Dummy, and their interaction term. We define as very large those banks with total assets in excess of $\$ 700$ billion, but our results are unchanged by considering instead $\$ 800$ or $\$ 900$ billion. ${ }^{11}$ The interaction terms on these regressions indicate that the increase in the risk-based capital ratio due to Class 1 enforcement actions is lower for very large banks (Column I), whereas the equivalent interaction term for the risk-weighted assets ratio (Column II) is not statistically significant. Thus, the very large banks decrease their risk-weighted assets ratios in the same fashion as other banks but face greater difficulty in raising an equal level of capital as a share of their risk-weighted assets. This is quite worrisome in light of the systemic character of these banks. These banks also have a lower response in their non-performing loans ratio, while the fluctuation in their risky assets is also lower relative to the rest of the banks in our sample.

\section{[Insert Table VII about here]}

A second robustness check (Panel B) comes from the examination of a sample cleaned of punished banks that are associated with any other major corporate event (M\&A, either as a target or acquirer; liquidation; or failure) during the sample period. The results are similar to those in Table IV, indicating that our main findings are not driven by other major corporate events.

\footnotetext{
${ }^{11}$ The Fed formally defines large banks as those with a minimum of $\$ 300$ billion in total assets. However, this corresponds to $25 \%$ of banks, whereas we are primarily interested in very large, systemic banks.
} 


\subsection{Timing of the Class 1 Enforcement Actions}

In this subsection, we focus our analysis on the timing of the Class 1 enforcement actions. We begin by examining the period during which the banks' risk-based capital ratios (risk-weighted assets ratios) deteriorate (increase) before the Class 1 enforcement actions are applied (timing). To this end, we construct two variables denoted Capital Quarter Fall and Risk-Weighted Assets Quarter Rise. Capital Quarter Fall is a cardinal variable that takes the value of the number of consecutive quarters that the risk-based capital ratio declines relative to its value in the previous quarter and zero otherwise. Essentially, this variable denotes the period of time during which a bank's risk-based capital ratio - and, by extension, the bank's financial soundness - displays continuous deterioration. In turn, Risk-Weighted Assets Quarter Rise is a cardinal variable that takes the value of the number of consecutive quarters that the risk-weighted assets ratio increases relative to its value in the previous quarter and zero otherwise. This variable is intended to capture the period of time during which a bank's risk-taking behavior displays continuous escalation. Both variables are constructed for every bank in the sample (see Table II for the summary statistics).

Table VIII reports the cross-tabulation of the two variables described above for the clean $(-4,+4)$ quarter event window of the Class 1 enforcement actions. As this table indicates, 633 of the 859 Class 1 enforcement actions, approximately $74 \%$ of the total sample, were imposed on banks with fewer than 2 consecutive quarters of declines in the risk-based capital ratio and increases in the risk-weighted assets ratio (sum of the four upper-left cells of Table VIII). This result could be regarded as indicating early employment of Class 1 enforcement actions relative to the escalating financial condition of ailing banks. The remaining Class 1 enforcement actions, approximately $26 \%$ of the total sample, were imposed with a rather significant delay, with maximum values reaching 20 quarters for the Capital Quarter Fall and 7 quarters for the Risk-Weighted Assets Quarter Rise. Of course, this is a crude distinction, which nevertheless offers insights into the timing of the Class 1 enforcement actions.

[Insert Table VIII about here] 
Next, and most important, we assess whether the timing of Class 1 enforcement actions affects their impact on the bank safety and soundness variables. We conduct this analysis in alternative ways. First, we reestimate the system of equations (1) and (2) by additionally including in equation (2) the variable Capital Quarter Fall along with its interaction term with the treatment variable. In this specification, a significant effect on the interaction term of Capital Quarter Fall with the treatment variable will suggest that the longer the period during which the bank's risk-based capital ratio deteriorates - thus, broadly speaking, the relatively later the Class 1 enforcement actions are imposed - the more intense the impact of such actions on the response variable. We perform a similar exercise with the introduction of Risk-Weighted Assets Quarter Rise into equation (2) along with its interaction term with the treatment variable. As with Capital Quarter Fall, a significant effect on the interaction term of Risk-Weighted Assets Quarter Rise with the treatment variable will indicate that the longer the period that a bank's risk-weighted assets ratio increases, the more intense the impact of Class 1 enforcement actions on the response variable.

We present the results for four response variables, namely, the risk-based capital ratio, the risk-weighted assets ratio, and the levels of the risk-based capital and risk-weighted assets in Columns I through IV of Panel A in Table IX. All models include the same variables as in Tables IV and V. In line with our expectations, we find the relevant interaction term in Columns I and II to be negative and strongly significant at the $1 \%$ level for the capital ratio and the level of capital, whereas the term is insignificant for the risk-weighted assets ratio and the level of risk-weighted assets. These findings indicate that the more the banks' safety and soundness problems are allowed to exacerbate over time without resorting to Class 1 enforcement actions, the more severe the deepening of the capital-raising difficulties for the ailing banks.

\section{[Insert Table IX about here]}

Notably, modeling the impact of the relatively late application of Class 1 enforcement actions using simply the interaction term of Capital Quarter Fall with the treatment variable implies, for example in the case of the risk-based capital ratio and according to the above results, that there will be an increasing decline in the response of the risk-based capital ratio to such actions as Capital Quarter Fall increases. To phrase it differently, such a linear modeling implies that the relatively later a Class 1 action is imposed on a bank faced with 
deteriorating risk-based capital standards, the less powerful its impact on improving the bank's capital adequacy position. However, this modeling choice could be relatively unrealistic if the bank's capital deteriorates in a diminishing way as Capital Quarter Fall increases, due to a bank's self-preservation or self-discipline mechanism and default avoidance considerations. To address this consideration, we introduce in Columns V through VIII of Panel A in Table IX Capital Quarter Fall Squared along with its interaction term with Enforcement Action. We find that, for the risk-based capital ratio reported in Column V, the interaction term between Enforcement Action and Capital Quarter Fall remains negative and statistically significant. We also find that the interaction term between Enforcement Action and Capital Quarter Fall Squared is positive and statistically significant. These findings demonstrate that the positive impact of Class 1 enforcement actions on a bank's risk-based capital ratio displays a diminishing trend when Capital Quarter Fall increases.

Panel B of Table IX replicates the results of Panel A, when the variable Risk-Weighted Assets Quarter Rise is employed along with its interaction term with the treatment variable. As Columns I through IV of this Panel indicate, none of the interaction terms between Risk-Weighted Assets Quarter Rise and the treatment variable is significant at the 5\% level. In Columns V through VIII, however, where the squared Risk-Weighted Assets Quarter Rise and its interaction term with the treatment variable are included in the model, the interaction term between Risk-Weighted Assets Quarter Rise and the treatment variable is significant with a negative sign for the risk-based capital ratio and the (log) level of risk based capital. These results demonstrate that the negative impact of Class 1 enforcement actions on a bank's risk-based capital ratio displays a diminishing trend when Risk-Weighted Assets Quarter Rise increases.

Arguably, these tests do not explicitly demonstrate whether the impact of Class 1 enforcement actions on the financial soundness of the troubled banks could be more positive if such actions had been applied sooner relative to the continuing deterioration of the banks' financial condition. Thus, we estimate a third set of regressions. We use the baseline models of Tables IV and V but only consider data for these bank-quarters for which the Capital Quarter Fall and the Risk-Weighted Quarter Rise take values of less than two. We expect that for this subsample, the unwelcomed effect of Class 1 enforcement actions on the risk-based capital ratio might be 
milder. We report the relevant results in Panel C of Table IX, for eight response variables, i.e., those employed in Table IV, along with the levels of the risk-based capital and risk-weighted assets.

The findings are quite intuitive. The risk-based capital ratio increases by 0.091 points one year after a Class 1 enforcement action. This increase is statistically significant at the $1 \%$ level. In turn, the risk-weighted assets ratio decreases by approximately 0.029 points, which implies that the portfolios of the punished banks become less risky on average. Perhaps more important, the 0.049 decline in the (log) level of risk-based capital in Column III of Panel B seems to indicate that when Class 1 enforcement actions are implemented earlier relative to the continuing deterioration of the banks' financial condition, the punished banks are provided with greater latitude to proceed with write-offs and portfolio restructuring. Moreover, the ROA of the punished banks one year after the event increases by 0.009 , indicating that earlier use of Class 1 enforcement actions relative to the persistent weakening of the banks' financial condition helps the punished banks to return to profitability one year after the event. In a similar vein, the $\sigma \mathrm{ROA}$ is half of the $\sigma \mathrm{ROA}$ of the full sample of the Class 1 enforcement actions (0.005 vis-a-vis 0.009 , as shown in Table IV). Finally, the non-performing loans ratio is smaller, while the liquidity ratio is insignificant.

Overall, these results lead to two crucial inferences. First, Class 1 enforcement actions are more effective in improving banks' risk-based capital ratios and reducing banks' risk-weighted assets ratios when such actions are imposed no more than two quarters after the decline of the punished banks' capital ratios and the rise of those banks' risk-weighted assets ratios. Second, those banks' overall financial soundness is fairly better compared to those of banks subject to a Class 1 enforcement action after a relatively prolonged period of continuous deterioration in their financial condition.

A potential limitation of this analysis is that the timing of a formal action may correlate with some unobserved bank or supervisor characteristics, which may also correlate with the size of the observed reactions once the enforcement actions are in place. For example, once supervisors decide to impose a formal action on the bank, the bank has the possibility to object, which may lead to a delay in the imposition or the implementation. Banks who object may be more unwilling to make corrective adjustments. Similar, selection issues could arise if the supervisors' choice of a formal vs. an informal action (as already discussed, informal actions that are not 
publicly available precede the formal actions that are publicly available) correlates with the banks' ability to correct the problems. In these cases, the timing of formal enforcement actions is endogenous to the imposition of Class 1 enforcement actions and the estimated coefficients of the interaction terms between the Class 1 enforcement action dummy and Capital Quarter Fall and Risk-Weighted Quarter Rise reported in Panels A and B of Table IX, would be biased upwards.

To at least partially account for this type of endogeneity, we examine the impact of the timing on the intensive margin (i.e., the impact of the timing, as captured by the Capital Quarter Fall variable, on the response variables only for the banks that received a Class 1 enforcement action). This entails a three-stage model for Equations (1) and (2), where the enforcement action dummy has been replaced by the cardinal variable Capital Quarter Fall. In the first stage, we estimate a zero-inflated Poisson model for Equation (1). We choose the zeroinflated Poisson model, instead of a standard Poisson model, because of the over-dispersion that the Capital Quarter Fall cardinal variable exhibits (as Table VIII indicates) and the result derived from the Vuong test. The next two stages are implemented by estimating Equation (2) using a simple 2SLS estimator, where the endogenous Capital Quarter Fall is instrumented with the fitted values from the zero-inflated Poisson model. We favor the 2SLS approach, instead of directly using the fitted values from the zero-inflated Poisson regression in a simple OLS regression in Equation (2), so as to correct the standard errors from the first stage and avoid the socalled forbidden regression. This procedure is suggested by Wooldridge (2010, p. 939) when using a first stage probit model and is also employed by many other studies to avoid the forbidden regression (e.g., Baier and Bergstrand, 2007; Berger and Roman, 2015).

The results, reported in Table $\mathrm{X}$, show that the intensive margin for the risk-based capital ratio is lower from that in Panel A of Table IX, while it remains unaffected for the other three response variables. These results suggest that when considering the potential endogeneity of the timing of an enforcement action, the impact of late enactment is less severe. In this context, the fact that the Gender of Supervisor's Bank Examiners is not observed at the bank-quarter level may constitute a more important limitation in addressing the potential endogeneities analyzed above.

[Insert Table X around here] 
As a final exercise, we estimate a treatment effects model as in equations (1) and (2), using the same control variables included in Table IV, where the dependent variable in the second stage is a dummy variable, denoted Inactive. This variable takes a value of one for the eight quarters before the effective quarter in which a bank is either liquidated or fails and zero otherwise. ${ }^{12}$ Similarly, we construct a second dummy variable, namely, Inactive One Year, which takes a value of one for the four quarters before the effective quarter in which a bank is either liquidated or fails and zero otherwise. Data for the construction of these two dummy variables are obtained from the FDIC website. The coefficient of the enforcement action dummy in the second stage will capture the impact of a Class 1 enforcement action on the probability of the liquidation or failure of the punished bank. The results from this exercise are reported in Table XI.

\section{[Insert Table XI around here]}

As Panel A in Table XI shows, when the full sample is considered in the analysis, the enforcement action dummy has a significant impact on the probability that the punished bank enters liquidation or fails within two years or within one year, with the coefficients being 0.434 and 0.293 , respectively. Interestingly, these coefficients decline by approximately half (that is, to 0.253 and 0.144 , respectively), when the analysis is performed for observations for which the Capital Quarter Fall and Risk-Weighted Assets Quarter Rise take values of less than two (Panel B). These results indicate that the imposition of Class 1 enforcement actions after a relatively prolonged period of continuous deterioration in a bank's financial condition is significantly and positively associated with the probability that the punished bank enters serious distress.

Overall, our findings demonstrate that the response to Question 2 regarding whether the timing of Class 1 enforcement actions affects the impact of such actions on the banks' capital and risk is positive. Our analysis offers evidence that as the consecutive quarters with deteriorating measures of bank health before the application of the Class 1 enforcement actions decrease, the disciplinary power of such actions increase, thus ensuring more

\footnotetext{
12 There is a sample of 517 Class 1 enforcement actions with a clean $(-4,+4)$ event window included in our analysis, where we have accounting data for the punished banks over the two-year time window after the event. The missing cases comprise banks that have terminated their operations (e.g., due to liquidation, failure, M\&A, etc.).
} 
effective implementation and compliance with the financial safety and soundness requirements. However, it should be born in mind that, due to the limitations introduced by the endogeneity of formal enforcement actions' timing discussed above, cautiousness is warranted in drawing generalized policy inferences.

\section{Conclusions}

In this paper, we assess and discuss the effect of formal enforcement actions intended to directly address core financial safety and soundness concerns (Class 1 enforcement actions) on banks' capital, risk, and performance. Our baseline results suggest that Class 1 enforcement actions curtail the punished banks' risk-taking incentives in the year after such actions. Class 1 enforcement actions lead the punished banks to constrain their risk-weighted assets through portfolio shrinkage and asset restructuring, most notably write-offs. Moreover, Class 1 enforcement actions tend to reduce the non-performing loans ratio, thereby also assisting in the recovery of the punished banks' credit risk profiles. The impact on the performance variables, however, is rather ambiguous; nonetheless, we find evidence of higher volatility of returns following the imposition of Class 1 enforcement actions, which implies an increased risk of insolvency.

We also find that the post-crisis period drives our baseline results. In particular, for the period following the onset of the financial crisis, we find that Class 1 enforcement actions caused the punished banks' capital to fall disproportionally to the decline in risk-weighted assets and that punished banks faced severe difficulty in reducing their non-performing loans ratio. This implies that the punished banks' scope to raise capital or liquidity and to restructure their asset portfolio in the midst of the financial crisis was seriously constrained. Our finding provides credible justification for reconsidering banking authorities' enforcement policy during periods of economy-wide turmoil, where troubled banks' latitude to take remedial actions in order to improve their safety and soundness condition seems to be significantly limited.

Moreover, we observe that the timing of the Class 1 enforcement actions affects the disciplinary impact of such actions on bank behavior. The 1991 US General Accounting Report concluded that more forceful actions need to be employed earlier in the supervisory process. Consistent with this finding, our analysis suggests that the longer it takes supervisors to impose Class 1 enforcement actions relative to the continuous deterioration of the 
banks' financial condition, the less influential is the impact of such actions in improving banks' risk-based capital ratios and reducing their risk-weighted asset ratios and the higher is the probability that the punished banks enter serious distress. In contrast, as the consecutive quarters with deteriorating measures of bank health before the application of Class 1 enforcement actions decrease, such actions appear to possess a superior stabilizing effect on banks' financial safety and soundness.

Although our findings offer fertile and novel ground for discussion on bank supervision and enforcement, we acknowledge that more work is required in terms of econometric identification, especially if information about the characteristics of bank examiners appointed to specific banks becomes available. This can also open up new pathways for the examination of the relationship between supervisory governance and supervisory effectiveness. 


\section{References}

Adams, R.B. and D. Ferreira. 2009. Women in the boardroom and their impact on governance and performance. Journal of Financial Economics: 94, 291-309.

Baier, S.L. and Bergstrand, J.H. 2007. Do free trade agreements actually increase members' international trade? Journal of International Economics: 71, 72-95.

Basel Committee on Banking Supervision. 2006. International Convergence of Capital Measurement and Capital Standards.

Basel Committee on Banking Supervision. 2012. Core Principles for Effective Banking Supervision.

Berger, A.N., Bouwman, C., Kick, T. and K. Schaeck. 2012. Bank risk taking and liquidity creation following regulatory interventions and capital support. Working Paper. Wharton Financial Institutions Center. Available at: http://papers.ssrn.com/sol3/papers.cfm?abstract_id=1908102.

Berger, A.N., Davies, S. and M. Flannery. 2000. Comparing market and supervisory assessments of bank performance: who knows what when? Journal of Money, Credit and Banking: 32, 641-667.

Berger A.N., Herring R.J. and G.P. Szegö. 1995. The role of capital in financial institutions. Journal of Banking and Finance: 19, 393-430.

Berger, A., Kyle, M.K. and Scalise, J.M., 2001. Did U.S. bank supervisors get tougher during the credit crunch? Did they get easier during the banking boom? Did it matter to bank lending? F. Mishkin, ed. Prudential Supervision: What Works and What Doesn't, University of Chicago Press, 301-356.

Berger, A.N., Roman, R.A., 2015. "Did TARP banks get competitive advantages?” Journal of Financial and Quantitative Analysis: forthcoming.

Brous, P. and K. Leggett. 1996. Wealth effects of enforcement actions against financially distressed banks. Journal of Financial Research: 19, 561-577.

Brunmeier J. and N. Willardson. September 2006. Supervisory enforcement actions since FIRREA and FDICIA: arbitrary, draconian and inflexible or a model of regulatory restraint? The Region (Federal Reserve Bank of Minneapolis Banking and Policy Issues Magazine). 
Caprio, G., Demirgüç-Kunt, A. and E. Kane. 2008. The 2007 meltdown in structured securitization: searching for lessons, not scapegoats. World Bank Policy Research Working Paper 4756.

Cole, R., Cornyn, G. and J. Gunther. 1995. FIMS: a new monitoring system for banking institutions. Federal Reserve Bulletin: 81, 1-15.

Curry, T. 1997. Bank examination and enforcement. History of the Eighties - Lessons for the Future: An Examination of the Banking Crises of the 1980s and Early 1990s, Volume I. FDIC, 421-475.

Curry, T., O’Keefe, J., Coburn, J. and L. Montgomery. 1999. Financial distressed banks: how effective are enforcement actions in the supervision process? FDIC Banking Review: 12, 1-18.

De Young, R., Flannery, M., Lang, W. and S. Sorescu. 2001. The information content of bank exam ratings and subordinated debt prices. Journal of Money, Credit and Banking: 33, 900-925.

Delis, M. and P. Staikouras. 2011. Supervisory effectiveness and bank risk. Review of Finance: 15, 511-543.

Demirgüc-Kunt, A. 1989. Deposit-institution failures: a review of empirical literature. Federal Reserve Bank of Cleveland Economic Review: 25, 2-18.

Demirgüç-Kunt, A., Detragiache, E. and T. Tressel. 2008. Banking on the principles: compliance with Basel Core Principles and bank soundness. Journal of Financial Intermediation: 17, 511-542.

Eynon, G., Hill, N. T. and K. T. Stevens. 1997. Factors that influence the moral reasoning abilities of accountants: implications for universities and the profession. Journal of Business Ethics: 16, 1297-1309.

Federal Deposit Insurance Corporation (FDIC). 2005. From the Examiner's Desk... The FDIC's Relationship Manager Program: A Win/Win Situation. Supervisory Insights: 2, 22-26.

Federal Deposit Insurance Corporation (FDIC). 2012 (updated October 2012). Risk Management Manual of Examination Policies.

Galloway, T., Lee, W. and D. Roden. 1997. Banks' changing incentives and opportunities for risk taking. Journal of Banking and Finance: 23, 509-527.

General Accounting Office (GAO). 1989. Testimony - Failed Thrifts: Internal Control Weaknesses Create an Environment Conducive to Fraud, Insider Abuse, and Related Unsafe Practices (GAO/T-AFMD 1989-4). 
General Accounting Office (GAO). 1991. Bank Supervision: Prompt and Forceful Regulatory Actions Needed (GAO/GGD-91-69).

Grier, W. 2007. Credit Analysis of Financial Institutions. Euromoney Institutional Investor Plc, London, UK.

Hardies, K., Breesch, D. and J. Branson. 2010. Are female auditors still women? Analyzing the sex differences affecting audit quality. Available at: http://papers.ssrn.com/sol3/papers.cfm?abstract_id=1409964.

Ittonen, K. and E. Vähämaa. 2012. Auditor’s gender and audit fees. International Journal of Auditing: 16, 1-18.

Ittonen, K., Vähämaa, E. and S. Vähämaa. 2013. Female auditors and accruals quality. Accounting Horizons: 27, 205-228.

Jordan, J., Peek, J. and E. Rosengren. 2000. The market reaction to the disclosure for supervisory information: implications for bank transparency. Journal of Financial Intermediation: 9, 298-319.

Lechner, M. 2011. The estimation of causal effects by difference-in-difference methods. Foundations and Trends in Econometrics: 4, 165-224.

Milne, A. 2002. Bank capital regulation as an incentive mechanism: implications for portfolio choice. Journal of Banking and Finance: 26, 1-23.

Office of the Comptroller of the Currency (OCC). 2007 (updated October 2014). Bank Supervision Process: Comptroller's Handbook.

Office of the Comptroller of the Currency (OCC). 2011. Policies and Procedures Manual: Bank Supervision Operations.

Peek, J. and E. Rosengren. 1995. Bank regulation and the credit crunch. Journal of Banking and Finance: 19, 679692.

Slovin, M., Sushka, M. and J. Polonchek. 1999. An analysis of contagion and competitive effects at commercial banks. Journal of Financial Economics: 54, 197-225.

Wooldridge, J.M., 2010. Econometric Analysis of Cross-Section and Panel Data. The MIT Press. 
Table I

List of Variables and Definitions

Variable

Definition

\section{Panel A. Response Variables}

For the main models examining the responses after the enactment of the Class 1 enforcement actions we consider the changes in the response variables from quarter $\mathrm{t}$ to quarter $\mathrm{t}+4$. For the examination of the pre-enforcement action period, i.e., estimation of equation (1), and the control variables entering equation (2) we consider the changes from quarter t-4 to t. Information for these variables is from the Call Reports.

Risk-Based Capital Ratio

Risk-Weighted Assets Ratio

Bank Profitability (ROA)

Standard Deviation of ROA ( $\sigma \mathrm{ROA})$

Non-Performing Loans Ratio

Liquidity Ratio

Risk-Based Capital

Risk-Weighted Assets

Risk-Weighted Assets 20

Risk-Weighted Assets 50

Risk-Weighted Assets 100

Total Loans

Total qualifying capital allowable under the risk-based capital guidelines / risk-weighted assets net of allowances and other deductions

Risk-weighted assets net of allowances and other deductions / total assets

Income or loss before income taxes and extraordinary items and other adjustments / total assets

Standard deviation of ROA, calculated for a rolling 12 quarters window

Nonaccrual total loans and lease finance receivables / total loans and leases net of unearned income

(Cash and balances due from depository institutions + fair value of held to maturity US treasury securities) / total assets

Natural logarithm of total qualifying capital allowable under the risk-based capital guidelines

Natural logarithm of risk-weighted assets net of allowances and other deductions

Natural logarithm of risk-weighted assets (20\% risk category)

Natural logarithm of risk-weighted assets (50\% risk category)

Natural logarithm of risk-weighted assets (100\% risk category)

Natural logarithm of total loans and leases net of unearned income

\section{$\underline{\text { Panel B. Explanatory Variables }}$}

The explanatory variables used in equation (1) or (2) are in changes from quarter t-4 to t, except for the enforcement action dummy. Variables employed in equation (2) are in changes from quarter $t$ to quarter $t+4$. We define only the explanatory variables that have not been defined as response variables above. Information for these variables is from the Call Reports, unless otherwise specified.

Enforcement Action

90-Day Delinquent Loans Ratio

Non-Interest Income Ratio

Available-for-Sale Securities Ratio

Bank Size

FDIC dummy
Dummy variable that equals 1 for the quarter during which a Class 1 enforcement action is imposed on a bank and 0 otherwise, while no other formal enforcement action of the same or different class has been imposed on the same bank within the $(-4,+4)$ quarter window around the event. Information for this variable comes from the websites of the FDIC and OCC.

Total loans and lease financing receivables past due 90 days or more and still accruing / total loans and leases net of unearned income

Total non-interest income / (total interest income + total non-interest income)

Available for sale securities / total assets

Natural logarithm of total assets

A dummy variable that takes the value of 1 if a bank is supervised by the FDIC and 0 if the bank is supervised by the OCC. 
GDP Growth

Federal Funds Rate

Financial Stress Index

Capital Quarter Fall

Risk-Weighted Assets Quarter Rise

Inactive

Inactive One Year

Gender of Supervisor's Bank Examiners
Change in the real GDP, year-on-year; obtained from the Federal Reserve Bank of St. Louis

Effective federal funds rate; obtained from the Federal Reserve Bank of St. Louis

Financial stress index; obtained from the Federal Reserve Bank of Kansas City

Capital Quarter Fall is a cardinal variable that takes the value of the number of consecutive quarters that the risk-based capital ratio is falling relative to its value in the previous quarter and zero otherwise, and is constructed for every bank in the sample.

Risk-Weighted Assets Quarter Rise is a cardinal variable that takes the value of the number of consecutive quarters that the risk-weighted assets ratio is rising relative to its value in the previous quarter and zero otherwise, and is constructed for every bank in the sample.

Inactive is a dummy variable that takes the value of 1 for the eight quarters before the effective quarter a bank is liquidated or failed, and zero otherwise.

Inactive is a dummy variable that takes the value of 1 for the four quarters before the effective quarter a bank is liquidated or failed, and zero otherwise.

\section{Panel C. Instrumental Variable}

This variable is constructed by first calculating the ratio of female to the total of bank examiners by state and year (quarter from 2007Q3 onward) for the FDIC and the OCC. Data are from the FedScope Employment Cubes, and are available online from the Office of Personnel Management. Subsequently, we use this as dependent variable in two regressions (one for each supervisor) with a linear trend and state fixed effects as explanatory variables. We use the residuals from these regressions as an instrumental variable in equation (1). 
Table II

\section{Summary Statistics}

The table reports descriptive statistics for the variables employed in the analysis. The sample period is 2000Q1-2010Q4. For the variables' definitions and sources, see Table I. Panel A reports descriptive statistics for the full sample. Panel B reports descriptive statistics at the event quarter for the banks that received a Class 1 enforcement action with a clean $(-4,+4)$ quarters event window, i.e., no other formal enforcement action of the same or different class has been imposed on the same bank within the $(-4,+4)$ quarter frame around the event.

\begin{tabular}{|c|c|c|c|c|c|c|c|c|c|c|}
\hline \multirow[b]{2}{*}{ Variable } & \multicolumn{5}{|c|}{ Panel A. Full Sample } & \multicolumn{5}{|c|}{$\frac{\text { Panel B. Banks that Received a Class } 1}{\text { Enforcement Action }}$} \\
\hline & Obs. & Mean & St. Dev. & Min. & Max. & Obs. & Mean & St. Dev. & Min. & Max. \\
\hline \multicolumn{11}{|l|}{ Bank Ratios } \\
\hline Risk-Based Capital Ratio & 263,217 & 0.174 & 0.123 & -0.190 & 11.493 & 859 & 0.135 & 0.058 & 0.050 & 1.006 \\
\hline Risk-Weighted Assets Ratio & 263,190 & 0.678 & 0.136 & 0.046 & 2.119 & 858 & 0.722 & 0.103 & 0.275 & 1.518 \\
\hline ROA & 263,217 & 0.008 & 0.011 & -0.390 & 0.951 & 859 & -0.006 & 0.018 & -0.238 & 0.121 \\
\hline$\sigma \mathrm{ROA}$ & 263,217 & 0.005 & 0.005 & 0.000 & 0.348 & 859 & 0.009 & 0.007 & 0.001 & 0.069 \\
\hline Non-Performing Loans Ratio & 263,217 & 0.010 & 0.017 & 0.000 & 0.236 & 859 & 0.054 & 0.043 & 0.000 & 0.229 \\
\hline Liquidity Ratio & 263,217 & 0.056 & 0.059 & 0.000 & 0.986 & 859 & 0.074 & 0.065 & 0.003 & 0.695 \\
\hline Non-Interest Income Ratio & 263,217 & 0.111 & 0.088 & -2.170 & 2.395 & 859 & 0.097 & 0.131 & -1.140 & 0.933 \\
\hline 90-Day Delinquent Loans Ratio & 263,217 & 0.003 & 0.007 & 0.000 & 0.078 & 859 & 0.005 & 0.010 & 0.000 & 0.059 \\
\hline Available-for-Sale Securities Ratio & 263,217 & 0.192 & 0.144 & 0.000 & 0.980 & 859 & 0.137 & 0.115 & 0.000 & 0.673 \\
\hline \multicolumn{11}{|l|}{ Bank (log) Levels } \\
\hline Risk-Based Capital & 263,215 & 9.431 & 1.153 & 5.384 & 16.252 & 859 & 9.515 & 1.132 & 6.377 & 14.523 \\
\hline Risk-Weighted Assets & 263,190 & 11.269 & 1.263 & 5.209 & 17.973 & 858 & 11.563 & 1.166 & 8.281 & 15.852 \\
\hline Risk-Weighted Assets 20 & 236,545 & 8.614 & 1.220 & 0.000 & 16.084 & 830 & 8.455 & 1.186 & 4.190 & 13.931 \\
\hline Risk-Weighted Assets 50 & 232,215 & 9.065 & 1.493 & 0.000 & 16.416 & 811 & 9.078 & 1.319 & 3.638 & 13.924 \\
\hline Risk-Weighted Assets 100 & 237,402 & 11.025 & 1.338 & 1.386 & 17.852 & 830 & 11.420 & 1.203 & 7.910 & 15.826 \\
\hline Total Loans & 263,217 & 11.186 & 1.302 & 0.693 & 17.827 & 859 & 11.510 & 1.175 & 7.886 & 15.833 \\
\hline Bank Size & 263,217 & 11.681 & 1.195 & 6.890 & 18.068 & 859 & 11.903 & 1.126 & 8.969 & 16.178 \\
\hline Capital Quarter Fall & 263,217 & 1.050 & 1.651 & 0 & 28 & 859 & 0.912 & 2.055 & 0 & 20 \\
\hline Risk-Weighted Assets Quarter Rise & 263,217 & 1.056 & 1.461 & 0 & 25 & 859 & 0.630 & 1.016 & 0 & 7 \\
\hline \multicolumn{11}{|l|}{ Macro Variables and Instruments } \\
\hline GDP Growth & 263,217 & 0.018 & 0.021 & -0.047 & 0.052 & & & & & \\
\hline Federal Funds Rate & 263,217 & 2.755 & 2.058 & 0.12 & 6.520 & & & & & \\
\hline Financial Stress Index & 263,217 & 0.323 & 1.187 & -0.824 & 5.136 & & & & & \\
\hline Gender of Supervisor's Bank Examiners & 263,217 & -0.003 & 0.043 & -0.514 & 0.629 & & & & & \\
\hline
\end{tabular}




\section{Table III}

\section{Formal Enforcement Actions by Year, Class and Supervisory Agency}

Panel A reports the number of formal enforcement actions by the FDIC and the OCC in the sample by year according to the four different Classes (for details, see Appendix A) for the period 2000-2010. Whenever two formal enforcement actions of different Classes that are imposed on a single bank become effective in the same quarter, or where the same supervisory decision contains sanctions belonging in more than one Class, we keep only the formal enforcement action of the higher Class. This choice is justified as the effect of the most important (from the perspective of bank safety and soundness) formal enforcement action outshines that of the less important one. Panel B reports the number of Class 1 enforcement actions by year and by supervisor (FDIC, OCC) for the period 2000-2010. Panel C reports the number of the Class 1 enforcement actions for FDIC and OCC with a clean $(-4,+4)$ quarters event window, i.e., no other formal enforcement action of the same or different class has been imposed on the same bank within the $(-4,+4)$ quarter frame around the event. These are the actions actually employed in our empirical analysis. The 859 Class 1 enforcement actions have been imposed on 797 distinct commercial banks.

\begin{tabular}{|c|c|c|c|c|c|c|c|c|}
\hline \multicolumn{6}{|c|}{$\frac{\text { Panel A. Number of Formal Enforcement Actions }}{\underline{\text { in the Sample per Class }}}$} & \multicolumn{2}{|c|}{$\frac{\frac{\text { Panel B. Number of Class } 1}{\text { Enforcement Actions per }}}{\underline{\text { Supervisory Agency }}}$} & \multirow{2}{*}{$\frac{\frac{\text { Panel C. Class } 1}{\text { Enforcement Actions with a }}}{\frac{\text { Clean Event Window for }}{\text { FDIC and OCC }}}$} \\
\hline & Class 1 & Class 2 & Class 3 & Class 4 & Total & FDIC & $\mathrm{OCC}$ & \\
\hline 2000 & 34 & 9 & 32 & 4 & 79 & 18 & 16 & 29 \\
\hline 2001 & 47 & 12 & 26 & 40 & 125 & 22 & 25 & 37 \\
\hline 2002 & 66 & 16 & 29 & 34 & 145 & 26 & 40 & 57 \\
\hline 2003 & 50 & 11 & 45 & 21 & 127 & 20 & 30 & 38 \\
\hline 2004 & 52 & 10 & 53 & 31 & 146 & 19 & 33 & 37 \\
\hline 2005 & 33 & 12 & 91 & 29 & 165 & 6 & 27 & 27 \\
\hline 2006 & 30 & 16 & 91 & 43 & 180 & 9 & 21 & 24 \\
\hline 2007 & 31 & 22 & 55 & 76 & 184 & 18 & 13 & 22 \\
\hline 2008 & 91 & 26 & 52 & 75 & 244 & 36 & 55 & 71 \\
\hline 2009 & 253 & 30 & 47 & 105 & 435 & 160 & 93 & 198 \\
\hline 2010 & 362 & 31 & 90 & 145 & 628 & 253 & 109 & 319 \\
\hline Total & 1,049 & 195 & 611 & 603 & 2,458 & 587 & 462 & 859 \\
\hline
\end{tabular}




\section{Table IV}

\section{Responses of Bank Ratios to Class 1 Enforcement Actions}

The table reports coefficient estimates and t-statistics (in parentheses) of the two-stage treatment effects model of equations (1) and (2). The sample period is 2000Q1-2010Q4. We use the Class 1 enforcement actions with a clean (-4, +4) quarters event window. The first stage includes all the explanatory variables of the second stage. Definitions for all variables are provided in Table I. The dependent variables of each regression are noted in the first line of the table below. The ***,**, and * marks denote statistical significance at the 1,5, and $10 \%$ level, respectively.

\begin{tabular}{|c|c|c|c|c|c|c|}
\hline $\begin{array}{l}\text { Dependent Variable (Change } \\
\text { from t to } t+4 \text { ): }\end{array}$ & $\begin{array}{c}\text { I } \\
\text { Risk-Based } \\
\text { Capital } \\
\text { Ratio } \\
\end{array}$ & $\begin{array}{c}\text { II } \\
\text { Risk- } \\
\text { Weighted } \\
\text { Assets Ratio }\end{array}$ & $\begin{array}{c}\text { III } \\
\text { ROA }\end{array}$ & $\begin{array}{c}\text { IV } \\
\sigma \mathrm{ROA}\end{array}$ & $\begin{array}{c}\mathbf{V} \\
\text { Non- } \\
\text { Performing } \\
\text { Loans Ratio }\end{array}$ & $\begin{array}{c}\text { VI } \\
\text { Liquidity } \\
\text { Ratio }\end{array}$ \\
\hline Class 1 Enforcement Action & $\begin{array}{c}0.067 * * * \\
(7.43)\end{array}$ & $\begin{array}{c}-0.032 * * * \\
(-3.49)\end{array}$ & $\begin{array}{l}0.001 \\
(0.26)\end{array}$ & $\begin{array}{c}0.009 * * * \\
(10.53)\end{array}$ & $\begin{array}{c}-0.018 * * * \\
(-8.46)\end{array}$ & $\begin{array}{c}0.024 * * * \\
\quad(4.11)\end{array}$ \\
\hline Risk-Based Capital Ratio & $\begin{array}{c}-0.204 * * * \\
(-82.75)\end{array}$ & $\begin{array}{c}0.035 * * * \\
(14.60)\end{array}$ & $\begin{array}{c}-0.002 * * * \\
(-2.73)\end{array}$ & $\begin{array}{c}0.002 * * * \\
(10.43)\end{array}$ & $\begin{array}{l}-0.001 \\
(-1.14)\end{array}$ & $\begin{array}{c}-0.017 * * * \\
(-10.90)\end{array}$ \\
\hline Risk-Weighted Assets Ratio & $\begin{array}{c}-0.042 * * * \\
(-18.21)\end{array}$ & $\begin{array}{c}-0.121 * * * \\
(-53.53)\end{array}$ & $\begin{array}{c}-0.002 * * \\
(-2.12)\end{array}$ & $\begin{array}{l}0.001 * * * \\
(5.92)\end{array}$ & $\begin{array}{l}-0.000 \\
(-0.27)\end{array}$ & $\begin{array}{c}-0.020 * * * \\
(-13.50)\end{array}$ \\
\hline Non-Performing Loans Ratio & $\begin{array}{c}-0.068 * * * \\
(-7.27)\end{array}$ & $\begin{array}{c}-0.327 * * * \\
(-35.53)\end{array}$ & $\begin{array}{l}-0.069 * * * \\
(-22.40)\end{array}$ & $\begin{array}{c}0.023 * * * \\
(25.97)\end{array}$ & $\begin{array}{l}-0.132 * * * \\
(-55.10)\end{array}$ & $\begin{array}{c}0.149 * * * \\
(25.08)\end{array}$ \\
\hline $\begin{array}{l}\text { 90-Day Delinquent Loans } \\
\text { Ratio }\end{array}$ & $\begin{array}{l}-0.019 \\
(-1.12)\end{array}$ & $\begin{array}{c}-0.103 * * * \\
(-6.19)\end{array}$ & $\begin{array}{c}-0.048 * * * \\
(-8.71)\end{array}$ & $\begin{array}{l}0.011 * * * \\
\quad(6.56)\end{array}$ & $\begin{array}{c}0.178 * * * \\
(41.13)\end{array}$ & $\begin{array}{c}0.038 * * * \\
\quad(3.57)\end{array}$ \\
\hline$\sigma \mathrm{ROA}$ & $\begin{array}{l}0.025 \\
(0.60)\end{array}$ & $\begin{array}{c}-0.187 * * * \\
(-4.53)\end{array}$ & $\begin{array}{l}-0.012 \\
(-0.85)\end{array}$ & $\begin{array}{c}0.114 * * * \\
(28.00)\end{array}$ & $\begin{array}{l}0.029 * * * \\
(2.67)\end{array}$ & $\begin{array}{c}0.056^{* *} \\
(2.11)\end{array}$ \\
\hline Non-Interest Income Ratio & $\begin{array}{l}0.023 * * * \\
(8.86)\end{array}$ & $\begin{array}{l}0.008 * * * \\
(2.95)\end{array}$ & $\begin{array}{c}-0.002 * * \\
(-2.47)\end{array}$ & $\begin{array}{c}0.001 * * * \\
(4.85)\end{array}$ & $\begin{array}{c}-0.006 * * * \\
(-9.52)\end{array}$ & $\begin{array}{c}-0.007 * * * \\
(-4.12)\end{array}$ \\
\hline Liquidity Ratio & $\begin{array}{c}0.054 * * * \\
(15.74)\end{array}$ & $\begin{array}{c}-0.046 * * * \\
(-13.64)\end{array}$ & $\begin{array}{l}0.001 \\
(0.53)\end{array}$ & $\begin{array}{l}0.000 \\
(0.18)\end{array}$ & $\begin{array}{l}-0.002 * \\
(-1.74)\end{array}$ & $\begin{array}{c}-0.174 * * * \\
(-79.89)\end{array}$ \\
\hline $\begin{array}{l}\text { Available-for-Sale Securities } \\
\text { Ratio }\end{array}$ & $\begin{array}{c}0.029 * * * \\
(12.65)\end{array}$ & $\begin{array}{c}-0.060 * * * \\
(-26.94)\end{array}$ & $\begin{array}{l}0.003 * * * \\
(3.40)\end{array}$ & $\begin{array}{l}0.000 \\
(0.47)\end{array}$ & $\begin{array}{c}-0.007 * * * \\
(-13.03)\end{array}$ & $\begin{array}{c}-0.027 * * * \\
(-19.03)\end{array}$ \\
\hline ROA & $\begin{array}{l}0.115^{* * * *} \\
(7.94)\end{array}$ & $\begin{array}{l}0.201 * * * \\
(14.13)\end{array}$ & $\begin{array}{c}-0.355^{* * *} \\
(-74.75)\end{array}$ & $\begin{array}{c}-0.009 * * * \\
(-6.61)\end{array}$ & $\begin{array}{c}-0.128 * * * \\
(-33.98)\end{array}$ & $\begin{array}{c}-0.159 * * * \\
(-17.35)\end{array}$ \\
\hline Bank's size & $\begin{array}{c}-0.028 * * * \\
(-31.91)\end{array}$ & $\begin{array}{c}0.028 * * * \\
(32.62)\end{array}$ & $\begin{array}{c}0.001 * * * \\
(4.85)\end{array}$ & $\begin{array}{c}-0.000 * * \\
(-2.32)\end{array}$ & $\begin{array}{c}0.005 * * * \\
(20.53)\end{array}$ & $\begin{array}{c}-0.016 * * * \\
(-28.94)\end{array}$ \\
\hline GDP Growth & $\begin{array}{c}0.017 * * * \\
(2.89)\end{array}$ & $\begin{array}{c}-0.071 * * * \\
(-12.17)\end{array}$ & $\begin{array}{c}-0.007 * * * \\
(-3.68)\end{array}$ & $\begin{array}{c}0.002 * * * \\
(3.47)\end{array}$ & $\begin{array}{c}-0.004 * * * \\
(-2.96)\end{array}$ & $\begin{array}{c}0.056^{* * *} \\
(14.97)\end{array}$ \\
\hline Federal Funds Rate & $\begin{array}{c}-0.000 * * * \\
(-6.98)\end{array}$ & $\begin{array}{c}0.004 * * * \\
(53.32)\end{array}$ & $\begin{array}{c}0.000 * * \\
(2.24)\end{array}$ & $\begin{array}{c}-0.000 * * * \\
(-4.32)\end{array}$ & $\begin{array}{c}-0.001 * * * \\
(-32.06)\end{array}$ & $\begin{array}{c}-0.003 * * * \\
(-61.04)\end{array}$ \\
\hline Financial Stress Index & $\begin{array}{c}-0.001 * * * \\
(-7.44)\end{array}$ & $\begin{array}{c}0.001 * * * \\
(10.24)\end{array}$ & $\begin{array}{c}-0.001 * * * \\
(-22.65)\end{array}$ & $\begin{array}{c}0.000 * * * \\
(16.00)\end{array}$ & $\begin{array}{c}0.001 * * * \\
(40.25)\end{array}$ & $\begin{array}{c}0.001 * * * \\
(20.17)\end{array}$ \\
\hline FDIC dummy & $\begin{array}{c}-0.001 * * * \\
(-4.29)\end{array}$ & $\begin{array}{l}0.000 \\
(1.47)\end{array}$ & $\begin{array}{l}-0.000 \\
(-0.31)\end{array}$ & $\begin{array}{l}0.000 \\
(1.16)\end{array}$ & $\begin{array}{c}0.000 * * * \\
(4.20)\end{array}$ & $\begin{array}{l}-0.000 \\
(-0.11)\end{array}$ \\
\hline Constant & $\begin{array}{c}0.002 * * * \\
(9.94)\end{array}$ & $\begin{array}{c}-0.001 * * \\
(-2.55)\end{array}$ & $\begin{array}{c}-0.001 * * * \\
(-9.11)\end{array}$ & $\begin{array}{l}0.000 \\
(1.12) \\
\end{array}$ & $\begin{array}{c}0.001 * * * \\
(21.92)\end{array}$ & $\begin{array}{c}0.004 * * * \\
(24.26)\end{array}$ \\
\hline \multicolumn{7}{|c|}{$\underline{\text { First-Stage }}$} \\
\hline $\begin{array}{l}\text { Gender of Supervisor's Bank } \\
\text { Examiners }\end{array}$ & $\begin{array}{c}1.377 * * * \\
(5.83)\end{array}$ & $\begin{array}{c}1.377 * * * \\
(5.83)\end{array}$ & $\begin{array}{c}1.377 * * * \\
(5.83)\end{array}$ & $\begin{array}{c}1.377 * * * \\
(5.83)\end{array}$ & $\begin{array}{l}1.365 * * * \\
(5.77)\end{array}$ & $\begin{array}{c}1.377 * * * \\
(5.83)\end{array}$ \\
\hline First Stage Pseudo-Rsq & 0.174 & 0.174 & 0.174 & 0.174 & 0.172 & 0.174 \\
\hline Hazard Lambda & $\begin{array}{c}-0.022 * * * \\
(-6.61)\end{array}$ & $\begin{array}{l}0.005 \\
(1.51)\end{array}$ & $\begin{array}{l}-0.000 \\
(-0.12)\end{array}$ & $\begin{array}{c}-0.003 * * * \\
(-10.11)\end{array}$ & $\begin{array}{c}0.009 * * * \\
(11.49)\end{array}$ & $\begin{array}{c}-0.006 * * * \\
(-2.81)\end{array}$ \\
\hline Observations & 263,170 & 263,164 & 263,176 & 263,176 & 262,937 & 263,177 \\
\hline
\end{tabular}




\section{Table V}

\section{Responses of Bank Variables in Levels to the Class 1 Enforcement Actions}

The table reports coefficient estimates and t-statistics (in parentheses) of the two-stage treatment effects model of equations (1) and (2). The sample period is 2000Q1-2010Q4. We use the Class 1 enforcement actions with a clean (-4, +4) quarters event window. The first stage includes all the explanatory variables of the second stage. Definitions for all variables are provided in Table I. The dependent variables of each regression are noted in the first line of the table below. The ***, **, and $*$ marks denote statistical significance at the 1,5 , and $10 \%$ level, respectively.

\begin{tabular}{|c|c|c|c|c|c|c|}
\hline $\begin{array}{l}\text { Dependent Variable (Change } \\
\text { from t to } t+4 \text { ): }\end{array}$ & $\begin{array}{c}\text { I } \\
\text { Risk-Based } \\
\text { Capital }\end{array}$ & $\begin{array}{c}\text { II } \\
\text { Risk- } \\
\text { Weighted } \\
\text { Assets }\end{array}$ & $\begin{array}{c}\text { III } \\
\text { Risk- } \\
\text { Weighted } \\
\text { Assets 20 }\end{array}$ & $\begin{array}{c}\text { IV } \\
\text { Risk- } \\
\text { Weighted } \\
\text { Assets 50 }\end{array}$ & $\begin{array}{c}\mathbf{V} \\
\text { Risk- } \\
\text { Weighted } \\
\text { Assets } 100\end{array}$ & $\begin{array}{c}\text { VI } \\
\text { Total loans }\end{array}$ \\
\hline Class 1 Enforcement Action & $\begin{array}{l}-0.031 \\
(-1.27)\end{array}$ & $\begin{array}{c}-0.074 * * * \\
(-2.85)\end{array}$ & $\begin{array}{c}-0.158 * * \\
(-2.37)\end{array}$ & $\begin{array}{l}0.208 * * * \\
(3.36)\end{array}$ & $\begin{array}{c}-0.089 * * * \\
(-2.70)\end{array}$ & $\begin{array}{l}-0.044 \\
(-1.49)\end{array}$ \\
\hline Risk-Based Capital Ratio & $\begin{array}{l}0.120 * * * \\
(18.86)\end{array}$ & $\begin{array}{l}0.132 * * * \\
(21.07)\end{array}$ & $\begin{array}{l}0.157 * * * \\
(8.94)\end{array}$ & $\begin{array}{l}-0.042^{*} \\
(-1.91)\end{array}$ & $\begin{array}{c}0.093 * * * \\
(10.94)\end{array}$ & $\begin{array}{l}0.065^{* * *} \\
\quad(9.46)\end{array}$ \\
\hline Risk-Weighted Assets Ratio & $\begin{array}{c}0.145 * * * \\
(23.79)\end{array}$ & $\begin{array}{c}0.035 * * * \\
(5.85)\end{array}$ & $\begin{array}{c}0.667 * * * \\
(40.49)\end{array}$ & $\begin{array}{c}0.300 * * * \\
(18.14)\end{array}$ & $\begin{array}{c}-0.072 * * * \\
(-9.07)\end{array}$ & \\
\hline Non-Performing Loans Ratio & $\begin{array}{c}-1.709 * * * \\
(-68.69)\end{array}$ & $\begin{array}{c}-1.417 * * * \\
(-56.37)\end{array}$ & $\begin{array}{c}-1.196 * * * \\
(-18.31)\end{array}$ & $\begin{array}{c}-0.944 * * * \\
(-14.90)\end{array}$ & $\begin{array}{c}-1.498 * * * \\
(-46.24)\end{array}$ & $\begin{array}{c}-1.761 * * * \\
(-61.82)\end{array}$ \\
\hline $\begin{array}{l}\text { 90-Day Delinquent Loans } \\
\text { Ratio }\end{array}$ & $\begin{array}{c}-0.428 * * * \\
(-9.52)\end{array}$ & $\begin{array}{c}-0.317 * * * \\
(-7.00)\end{array}$ & $\begin{array}{l}-0.151 \\
(-1.25)\end{array}$ & $\begin{array}{c}-0.298 * * \\
(-2.51)\end{array}$ & $\begin{array}{c}-0.370 * * * \\
(-6.16)\end{array}$ & $\begin{array}{c}-0.456 * * * \\
(-8.91)\end{array}$ \\
\hline$\sigma \mathrm{ROA}$ & $\begin{array}{c}-1.855^{* * *} \\
(-16.67)\end{array}$ & $\begin{array}{c}-3.264 * * * \\
(-29.21)\end{array}$ & $\begin{array}{c}-3.034 * * * \\
(-10.30)\end{array}$ & $\begin{array}{c}-3.985 * * * \\
(-12.49)\end{array}$ & $\begin{array}{l}-2.616 * * * \\
(-17.85)\end{array}$ & $\begin{array}{c}-3.146 * * * \\
(-24.85)\end{array}$ \\
\hline Non-Interest Income Ratio & $\begin{array}{c}-0.028 * * * \\
(-4.11)\end{array}$ & $\begin{array}{c}-0.065^{* * *} \\
(-9.32)\end{array}$ & $\begin{array}{c}-0.041 * * \\
(-2.30)\end{array}$ & $\begin{array}{c}-0.044 * * \\
(-2.49)\end{array}$ & $\begin{array}{c}-0.059 * * * \\
(-6.64)\end{array}$ & $\begin{array}{l}-0.012 \\
(-1.59)\end{array}$ \\
\hline Liquidity Ratio & $\begin{array}{c}-0.136 * * * \\
(-14.93)\end{array}$ & $\begin{array}{c}-0.295 * * * \\
(-32.06)\end{array}$ & $\begin{array}{c}-0.389 * * * \\
(-16.02)\end{array}$ & $\begin{array}{c}-0.066 * * * \\
(-2.73)\end{array}$ & $\begin{array}{c}-0.340 * * * \\
(-28.31)\end{array}$ & $\begin{array}{c}-0.249 * * * \\
(-24.59)\end{array}$ \\
\hline $\begin{array}{l}\text { Available-for-Sale Securities } \\
\text { Ratio }\end{array}$ & $\begin{array}{c}-0.032 * * * \\
(-5.42)\end{array}$ & $\begin{array}{c}-0.154 * * * \\
(-25.57)\end{array}$ & $\begin{array}{c}0.177 * * * \\
(11.08)\end{array}$ & $\begin{array}{l}-0.016 \\
(-1.00)\end{array}$ & $\begin{array}{c}-0.228 * * * \\
(-28.76)\end{array}$ & $\begin{array}{c}-0.180 * * * \\
(-27.73)\end{array}$ \\
\hline ROA & $\begin{array}{l}1.391 * * * \\
(36.22)\end{array}$ & $\begin{array}{l}0.972 * * * \\
(25.15)\end{array}$ & $\begin{array}{l}1.131 * * * \\
(10.76)\end{array}$ & $\begin{array}{c}0.494 * * * \\
(4.32)\end{array}$ & $\begin{array}{c}1.201 * * * \\
(23.01)\end{array}$ & $\begin{array}{c}0.485^{* * * *} \\
(10.98)\end{array}$ \\
\hline Bank’s size & $\begin{array}{c}0.249 * * * \\
(107.85)\end{array}$ & & & & & \\
\hline GDP Growth & $\begin{array}{c}-0.104 * * * \\
(-6.60)\end{array}$ & $\begin{array}{c}-0.299 * * * \\
(-18.84)\end{array}$ & $\begin{array}{c}-0.096 * * \\
(-2.37)\end{array}$ & $\begin{array}{c}0.255^{* * *} * \\
(6.48)\end{array}$ & $\begin{array}{c}-0.394 * * * \\
(-19.48)\end{array}$ & $\begin{array}{c}-0.331 * * * \\
(-18.45)\end{array}$ \\
\hline Federal Funds Rate & $\begin{array}{c}0.001 * * * \\
(6.14)\end{array}$ & $\begin{array}{c}0.006 * * * \\
(30.37)\end{array}$ & $\begin{array}{c}-0.009 * * * \\
(-17.54)\end{array}$ & $\begin{array}{c}-0.002 * * * \\
(-4.93)\end{array}$ & $\begin{array}{c}0.008 * * * \\
(30.57)\end{array}$ & $\begin{array}{c}0.006 * * * \\
(30.06)\end{array}$ \\
\hline Financial Stress Index & $\begin{array}{c}-0.003^{* * *} \\
(-10.93)\end{array}$ & $\begin{array}{c}0.002 * * * \\
(7.93)\end{array}$ & $\begin{array}{c}-0.009 * * * \\
(-12.18)\end{array}$ & $\begin{array}{c}0.010 * * * \\
(13.95)\end{array}$ & $\begin{array}{c}0.003 * * * \\
(7.31)\end{array}$ & $\begin{array}{c}0.002 * * * \\
(6.86)\end{array}$ \\
\hline FDIC dummy & $\begin{array}{c}-0.003 \text { *** } \\
(-4.82)\end{array}$ & $\begin{array}{c}0.004 * * * \\
(5.03)\end{array}$ & $\begin{array}{l}-0.000 \\
(-0.22)\end{array}$ & $\begin{array}{c}0.008 * * * \\
(4.41)\end{array}$ & $\begin{array}{c}0.007 * * * \\
(7.07)\end{array}$ & $\begin{array}{c}0.004 * * * \\
(4.58)\end{array}$ \\
\hline Constant & $\begin{array}{c}0.049 * * * \\
(74.25) \\
\end{array}$ & $\begin{array}{c}0.066 * * * \\
(103.97) \\
\end{array}$ & $\begin{array}{c}0.045 * * * \\
(26.55) \\
\end{array}$ & $\begin{array}{c}0.044 * * * \\
(27.01)\end{array}$ & $\begin{array}{c}0.067 * * * \\
(79.55) \\
\end{array}$ & $\begin{array}{c}0.063 * * * \\
(88.16)\end{array}$ \\
\hline \multicolumn{7}{|c|}{ First-Stage } \\
\hline $\begin{array}{l}\text { Gender of Supervisor's Bank } \\
\text { Examiners }\end{array}$ & $\begin{array}{c}1.373 * * * \\
(5.81)\end{array}$ & $\begin{array}{c}1.502 * \bar{*} \\
(6.43)\end{array}$ & $\begin{array}{c}1.622 * * * \\
(6.86)\end{array}$ & $\begin{array}{c}1.603 * * * \\
(6.72)\end{array}$ & $\begin{array}{c}1.623 * * * \\
(6.87)\end{array}$ & $\begin{array}{l}1.572 * * * \\
(6.77)\end{array}$ \\
\hline First Stage Pseudo-Rsq & 0.175 & 0.154 & 0.154 & 0.158 & 0.154 & 0.147 \\
\hline Hazard Lambda & $\begin{array}{c}-0.024 * * * \\
(-2.68)\end{array}$ & $\begin{array}{c}-0.024 * * \\
(-2.57)\end{array}$ & $\begin{array}{l}0.031 \\
(1.28)\end{array}$ & $\begin{array}{c}-0.123 * * * \\
(-5.44)\end{array}$ & $\begin{array}{l}-0.022 * \\
(-1.80)\end{array}$ & $\begin{array}{c}-0.038 * * * \\
(-3.57)\end{array}$ \\
\hline Observations & 263,093 & 263,164 & 236,386 & 231,420 & 237,358 & 263,177 \\
\hline
\end{tabular}


Table VI

Responses of Bank Variables to the Class 1 Enforcement Actions in the Pre-Crisis and Post-Crisis periods

The table reports coefficient estimates and t-statistics (in parentheses) of the two-stage treatment effects model of equations (1) and (2). We use the Class 1 enforcement actions with a clean $(-4,+4)$ quarters event window. The table replicates the regressions of Tables IV and V including an interaction term between the enforcement action variable and a dummy variable that takes the value one in the period after 2007Q2 and zero otherwise. For expositional brevity only the results on the main and interaction terms involving the enforcement action variable are presented. Definitions for all variables are provided in Table I. The dependent variables of each regression are noted above each of the presented estimated coefficients. The ***,**, and * marks denote statistical significance at the 1 , 5 , and $10 \%$ level, respectively.

\begin{tabular}{lcccccc}
\hline $\begin{array}{l}\text { Dependent Variable } \\
\text { (Change from t to t+4): }\end{array}$ & $\begin{array}{c}\text { I } \\
\text { Risk-Based } \\
\text { Capital Ratio }\end{array}$ & $\begin{array}{c}\text { II } \\
\text { Risk- } \\
\text { Weighted } \\
\text { Assets Ratio }\end{array}$ & ROA & III & V & VI \\
Non- & (ROA & $\begin{array}{c}\text { Performing } \\
\text { Loans Ratio }\end{array}$ & $\begin{array}{c}\text { Liquidity } \\
\text { Ratio }\end{array}$ \\
\hline Class 1 Enforcement & $0.100^{* * *}$ & $-0.039^{* * *}$ & 0.000 & $0.011^{* * *}$ & $-0.031^{* * *}$ & 0.008 \\
Action & $(9.24)$ & $(-3.43)$ & $(0.11)$ & $(11.19)$ & $(-12.80)$ & $(1.11)$ \\
After Crisis Dummy & $0.001^{* * *}$ & $-0.021^{* * *}$ & $-0.001^{* * *}$ & $0.000^{* * *}$ & $0.005^{* * *}$ & $0.016^{* * *}$ \\
Class 1 Enforcement & $(3.13)$ & $(-72.41)$ & $(-12.52)$ & $(3.25)$ & $(65.50)$ & $(86.21)$ \\
Action * After Crisis & $-0.023^{* * *}$ & $0.016^{* * *}$ & 0.001 & $-0.002^{* * *}$ & $0.005^{* * *}$ & 0.002 \\
Dummy & $(-5.53)$ & $(3.58)$ & $(0.60)$ & $(-4.51)$ & $(6.75)$ & $(0.67)$ \\
\hline
\end{tabular}

\begin{tabular}{lcccccc}
\hline & & \multicolumn{3}{c}{ First-Stage } & & \\
Gender of Supervisor's & $1.377 * * *$ & $1.377 * * *$ & $1.377 * * *$ & $1.377 * * *$ & $1.365 * * *$ & $1.377 * * *$ \\
Bank Examiners & $(5.83)$ & $(5.83)$ & $(5.83)$ & $(5.83)$ & $(5.77)$ & $(5.83)$ \\
\hline Observations & 263,170 & 263,164 & 263,176 & 263,176 & 262,937 & 263,177 \\
\hline \hline
\end{tabular}

\begin{tabular}{lcccccc}
$\begin{array}{l}\text { Dependent Variable } \\
\text { (Change from t to t+4): }\end{array}$ & $\begin{array}{c}\text { ViI } \\
\text { Risk-Based } \\
\text { Capital }\end{array}$ & $\begin{array}{c}\text { VIII } \\
\text { Risk- } \\
\text { Weighted } \\
\text { Assets }\end{array}$ & $\begin{array}{c}\text { IX } \\
\text { Risk- } \\
\text { Weighted } \\
\text { Assets 20 }\end{array}$ & $\begin{array}{c}\mathbf{X} \\
\text { Risk- } \\
\text { Weighted } \\
\text { Assets 50 }\end{array}$ & $\begin{array}{c}\text { XI } \\
\text { Risk- } \\
\text { Weighted } \\
\text { Assets 100 }\end{array}$ & Total loans \\
\hline Class 1 Enforcement & $0.187^{* * *}$ & $-0.056^{*}$ & 0.070 & $0.181^{* *}$ & $-0.105^{* * *}$ & -0.036 \\
Action & $(6.47)$ & $(-1.78)$ & $(0.85)$ & $(2.38)$ & $(-2.59)$ & $(-1.00)$ \\
After Crisis Dummy & $-0.033^{* * *}$ & $-0.050^{* * *}$ & $-0.051^{* * *}$ & $0.018^{* * *}$ & $-0.057^{* * *}$ & $-0.046^{* * *}$ \\
Class 1 Enforcement & $(-42.37)$ & $(-63.45)$ & $(-25.55)$ & $(9.12)$ & $(-57.75)$ & $(-51.64)$ \\
Action * After Crisis & $-0.131^{* * *}$ & $0.025 * *$ & $-0.117 * * *$ & 0.007 & $0.053^{* * *}$ & $0.032^{* * *}$ \\
Dummy & $(-11.52)$ & $(1.99)$ & $(-3.57)$ & $(0.23)$ & $(3.26)$ & $(2.31)$ \\
\hline
\end{tabular}

\begin{tabular}{lcccccc} 
& \multicolumn{9}{c}{ First-Stage } \\
Gender of Supervisor's & $1.373 * * *$ & $1.502^{* * *}$ & $1.622 * * *$ & $1.603 * * *$ & $1.623 * * *$ & $1.572 * * *$ \\
Bank Examiners & $(5.81)$ & $(6.43)$ & $(6.86)$ & $(6.72)$ & $(6.87)$ & $(6.77)$ \\
\hline Observations & 263,093 & 263,164 & 236,386 & 231,420 & 237,358 & 263,177 \\
\hline \hline
\end{tabular}




\section{Table VII}

\section{Responses of Bank Ratios to the Class 1 Enforcement Actions: Sensitivity Analysis}

The table reports coefficient estimates and t-statistics (in parentheses) of the two-stage treatment effects model of equations (1) and (2). We use the Class 1 enforcement actions with a clean $(-4,+4)$ quarters event window. In Panel A an interaction term is introduced between the enforcement action variable and bank's size. In Panel B the punished banks that also had other important corporate events (M\&As, liquidations and failures) during the sample period are excluded from the analysis. For expositional brevity only the results on the enforcement action variable and on the instruments in equation (1) are presented. Definitions for all variables are provided in Table I. The dependent variables of each regression are noted in the first line of the table below and are in ratios. The ***,**, and * marks denote statistical significance at the 1,5 , and $10 \%$ level, respectively.

\begin{tabular}{lcccccc}
$\begin{array}{l}\text { Dependent Variable } \\
\text { (Change from } t \text { to } t+4):\end{array}$ & $\begin{array}{c}\text { I } \\
\text { Risk-Based } \\
\text { Capital Ratio }\end{array}$ & $\begin{array}{c}\text { Risk- } \\
\text { Weighted } \\
\text { Assets Ratio }\end{array}$ & ROA & oROA & $\begin{array}{c}\text { II } \\
\text { Pon- } \\
\text { Lerforming }\end{array}$ & $\begin{array}{c}\text { Liquidity } \\
\text { Ratio }\end{array}$ \\
\hline
\end{tabular}

\section{Panel A. Banks with more than 700 mil USD assets}

\begin{tabular}{|c|c|c|c|c|c|c|}
\hline $\begin{array}{l}\text { Class } 1 \text { Enforcement } \\
\text { Action }\end{array}$ & $\begin{array}{c}0.069 * * * \\
(7.55)\end{array}$ & $\begin{array}{c}-0.033 * * * \\
(-3.59)\end{array}$ & $\begin{array}{l}0.000 \\
(0.06)\end{array}$ & $\begin{array}{c}0.009 * * * \\
(10.85)\end{array}$ & $\begin{array}{c}-0.020 * * * \\
(-9.19)\end{array}$ & $\begin{array}{c}0.025 * * * \\
(4.22)\end{array}$ \\
\hline Large Bank Dummy & $\begin{array}{c}0.006 * * * \\
(12.35)\end{array}$ & $\begin{array}{c}-0.006 * * * \\
(-13.60)\end{array}$ & $\begin{array}{c}-0.001 * * * \\
(-5.11)\end{array}$ & $\begin{array}{c}0.000 * * * \\
(3.74)\end{array}$ & $\begin{array}{c}0.002 * * * \\
(20.77)\end{array}$ & $\begin{array}{c}0.001 * * * \\
(5.06)\end{array}$ \\
\hline $\begin{array}{l}\text { Class } 1 \text { Enforcement } \\
\text { Action * Large Bank } \\
\text { Dummy }\end{array}$ & $-0.013^{*}$ & 0.010 & 0.004 & $\begin{array}{c}-0.002^{* * *} \\
(-3.15)\end{array}$ & $\begin{array}{c}0.008^{* * *} * \\
(5.03)\end{array}$ & -0.006 \\
\hline \multicolumn{7}{|c|}{ First-Stage } \\
\hline $\begin{array}{l}\text { Gender of Supervisor's } \\
\text { Bank Examiners }\end{array}$ & $\begin{array}{c}1.377 * * * \\
(5.83)\end{array}$ & $\begin{array}{c}1.377 * * * \\
(5.83)\end{array}$ & $\begin{array}{c}1.377 * * * \\
(5.83)\end{array}$ & $\begin{array}{c}1.377 * * * \\
(5.83)\end{array}$ & $\begin{array}{c}1.365 * * * \\
(5.77)\end{array}$ & $\begin{array}{c}1.377 * * * \\
(5.83)\end{array}$ \\
\hline Observations & 263,170 & 263,164 & 263,176 & 263,176 & 262,937 & 263,177 \\
\hline
\end{tabular}

Panel B: Excluding Punished Banks Engaged in Other Corporate Events During Sample Period

\begin{tabular}{|c|c|c|c|c|c|c|}
\hline $\begin{array}{l}\text { Class } 1 \text { Enforcement } \\
\text { Action }\end{array}$ & $\begin{array}{c}0.059 * * * \\
(5.80)\end{array}$ & $\begin{array}{c}-0.040 * * * \\
(-3.80)\end{array}$ & $\begin{array}{l}-0.006^{*} \\
(-1.74)\end{array}$ & $\begin{array}{c}0.011^{* * *} \\
(11.13)\end{array}$ & $\begin{array}{c}-0.016^{* * *} \\
(-6.84)\end{array}$ & $\begin{array}{c}0.018 * * * \\
(2.61)\end{array}$ \\
\hline \multicolumn{7}{|c|}{ First-Stage } \\
\hline $\begin{array}{l}\text { Gender of Supervisor's } \\
\text { Bank Examiners }\end{array}$ & $\begin{array}{c}1.650 * * * \\
(6.11)\end{array}$ & $\begin{array}{c}1.649 * * * \\
(6.11)\end{array}$ & $\begin{array}{c}1.650^{* * *} \\
(6.11)\end{array}$ & $\begin{array}{c}1.650 * * * \\
(6.11)\end{array}$ & $\begin{array}{c}1.641 * * * \\
(6.07)\end{array}$ & $\begin{array}{c}1.650 * * * \\
(6.11)\end{array}$ \\
\hline Observations & 235,361 & 235,356 & 235,367 & 235,367 & 235,246 & 235,367 \\
\hline
\end{tabular}




\section{Table VIII}

Cross-tabulations - Capital Quarter Fall and Risk-Weighted Assets Quarter Rise

Each cell in this table reports the number of the Class 1 enforcement actions with a clean $(-4,+4)$ quarters event window with respect to Capital Quarter Fall and Risk-Weighted Assets Quarter Rise. Quarter fall is a cardinal variable that takes the value of the number of consecutive quarters that the risk-based capital ratio is falling relative to its value in the previous quarter and zero otherwise. Quarter rise is a cardinal variable that takes the value of the number of consecutive quarters that the risk-weighted assets ratio is rising relative to its value in the previous quarter and zero otherwise

\begin{tabular}{|c|c|c|c|c|c|c|c|c|c|}
\hline \multirow{2}{*}{$\begin{array}{l}\text { Risk-Weighted Assets } \\
\text { Quarter Rise }\end{array}$} & \multicolumn{7}{|c|}{ Capital Quarter Fall } & \multirow[b]{2}{*}{$17-20$} & \multirow{2}{*}{ Row Tota } \\
\hline & 0 & 1 & $2-3$ & $4-5$ & $6-8$ & $9-12$ & $13-16$ & & \\
\hline 0 & 351 & 85 & 43 & 18 & 10 & 2 & 1 & 2 & 512 \\
\hline 1 & 133 & 64 & 29 & 9 & 3 & 2 & 2 & 0 & 242 \\
\hline $2-3$ & 49 & 15 & 10 & 6 & 2 & 0 & 1 & 1 & 84 \\
\hline $4-5$ & 9 & 2 & 3 & 1 & 1 & 0 & 0 & 0 & 16 \\
\hline $6-7$ & 2 & 2 & 1 & 0 & 0 & 0 & 0 & 0 & 5 \\
\hline Column Total & 544 & 168 & 86 & 34 & 16 & 4 & 4 & 3 & 859 \\
\hline
\end{tabular}




\section{Table IX}

\section{Timing of the Class 1 Enforcement Actions:}

Does the Use of the Class 1 Enforcement Actions at a Relatively Earlier/ Later Stage of the Supervisory Process Affect their Impact on Bank Safety and Soundness?

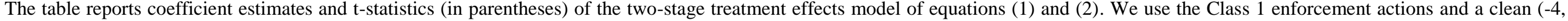

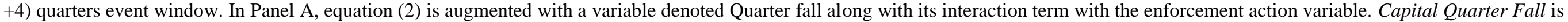

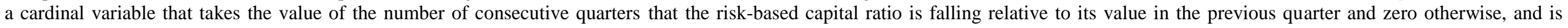

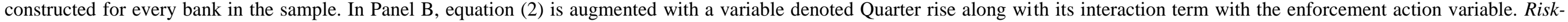

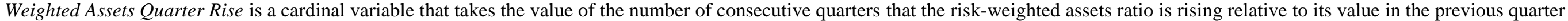

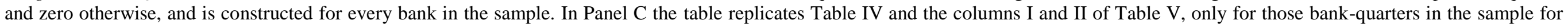

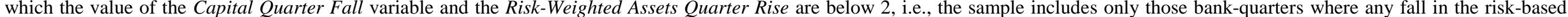

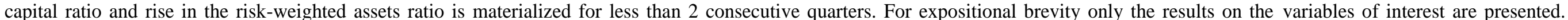

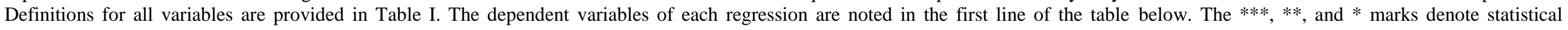
significance at the 1,5 , and $10 \%$ level, respectively.

\begin{tabular}{|c|c|c|c|c|c|c|c|c|}
\hline & $\mathbf{I}$ & II & III & IV & $\mathbf{V}$ & VI & VII & VIII \\
\hline Dependent Variable (Change from $t$ to $t+4$ ): & $\begin{array}{c}\text { Risk-Based } \\
\text { Capital Ratio }\end{array}$ & $\begin{array}{l}\text { Risk-Weighted } \\
\text { Assets Ratio }\end{array}$ & $\begin{array}{c}\text { Risk-Based } \\
\text { Capital }\end{array}$ & $\begin{array}{c}\text { Risk-Weighted } \\
\text { Assets }\end{array}$ & $\begin{array}{c}\text { Risk-Based } \\
\text { Capital Ratio }\end{array}$ & $\begin{array}{c}\text { Risk-Weighted } \\
\text { Assets Ratio }\end{array}$ & $\begin{array}{c}\text { Risk-Based } \\
\text { Capital }\end{array}$ & $\begin{array}{c}\text { Risk-Weighted } \\
\text { Assets }\end{array}$ \\
\hline
\end{tabular}

\section{Panel A. Interaction Terms between Class 1 Enforcement Action and Capital Quarter Fall}

\section{Class 1 Enforcement Action}

Capital Quarter Fall

Capital Quarter Fall Squared

Class 1 Enforcement Action * Capital

Quarter Fall

Class 1 Enforcement Action * Capital

Quarter Fall squared

Observations

$0.074 * * *$
$(8.24)$
$-0.001 * * *$

$(-11.99)$

\begin{abstract}
$-0.005 * * *$
\end{abstract}
$(-5.87)$

263,170
$-0.034 * *$
$(-3.76)$
$0.000 * * *$

(6.65)

$-0.012$

$(-0.51)$

$-0.001 * * *$

$(-3.67)$

0.001

(0.69)

$-0.031 * * *$

$-0.031 * * *$
$(-12.04)$

263,164
$-0.095 * * *$
$(-3.65)$
$0.006 * * *$

(33.32)

$-0.001$

(-0.49)

\section{$0.073 * * *$ \\ (8.16)}

$-0.001 * * *$

$(-14.25)$

$0.000 * * *$

(8.16)

$-0.009 * *$

$-0.009 * * *$

$(-5.83)$

$0.000 * * *$

(2.64)

263,170

$-0.034 * * *$

$(-3.75)$

$0.001 * * *$

(10.92)

$-0.000 * * *$

(-8.78)

0.003

(1.50)

$-0.000$

$(-1.00)$

263,164

$-0.013$

(-0.53)

$-0.002 * * *$

(-8.35)

$0.000 * * *$

(8.11)

$-0.036 * * *$

$(-7.99)$

0.000

(1.02)

263,093

$-0.095 * * *$

$(-3.63)$

$0.008 * * *$

(28.45)

$-0.000 * * *$

(-7.08)

0.004

(0.92)

$-0.000$

(-1.19)

263,164

\section{Panel B. Interaction Terms between Class 1 Enforcement Action and Risk-Weighted Assets Quarter Rise}

\section{Class 1 Enforcement Action}

Risk-Weighted Assets Quarter Rise

Risk-Weighted Assets Quarter Rise Squared

$\begin{array}{cccc}0.065 * * * & -0.033 * * * & -0.040 & -0.074 * * * \\ (7.07) & (-3.54) & (-1.59) & (-2.80) \\ -0.000 * * * & 0.001 * * * & 0.001 * * * & 0.003 * * *\end{array}$

$(-5.44)$

(12.77)
$0.061 * * *$

(6.55)

$-0.000 * * *$

(-3.04)

$-0.000$

(-1.27)
$-0.033 * * *$

(-3.49)

$0.000 * * *$

(3.98)

$0.000 * * *$

(7.57)
$-0.051 * *$

(-2.02)

$0.002 * * *$

(5.32)

$-0.000 * * *$

$(-4.31)$
$-0.070 * * *$

$0.003 * * *$

(10.15)

$-0.000 * *$

$(-2.45)$ 


\begin{tabular}{|c|c|c|c|c|c|c|c|c|}
\hline $\begin{array}{l}\text { Class } 1 \text { Enforcement Action * Risk- } \\
\text { Weighted Assets Quarter Rise }\end{array}$ & $\begin{array}{l}-0.003 * \\
(-1.67)\end{array}$ & $\begin{array}{l}0.001 \\
(0.67)\end{array}$ & $\begin{array}{l}-0.008 \\
(-1.49)\end{array}$ & $\begin{array}{l}0.006 \\
(1.05)\end{array}$ & $\begin{array}{c}-0.007 * * * \\
(-2.75)\end{array}$ & $\begin{array}{l}0.001 \\
(0.35)\end{array}$ & $\begin{array}{c}-0.018 * * * \\
(-2.66)\end{array}$ & $\begin{array}{l}0.009 \\
(1.36)\end{array}$ \\
\hline $\begin{array}{l}\text { Class } 1 \text { Enforcement Action * Risk- } \\
\text { Weighted Assets Quarter Rise squared }\end{array}$ & & & & & $\begin{array}{c}0.002 * * \\
(2.26)\end{array}$ & $\begin{array}{l}0.000 \\
(0.41)\end{array}$ & $\begin{array}{c}0.006 * * \\
(2.26)\end{array}$ & $\begin{array}{l}-0.002 \\
(-0.93)\end{array}$ \\
\hline Observations & 263,170 & 263,164 & 263,093 & 263,164 & 263,170 & 263,164 & 263,093 & 263,164 \\
\hline
\end{tabular}

Panel C. Including Only Bank-Quarters during which the Capital Quarter Fall and the Risk-Weighted Assets Quarter Rise is less than two

\begin{tabular}{|c|c|c|c|c|c|c|c|c|}
\hline & $\mathbf{I}$ & II & III & IV & & & & \\
\hline & $\begin{array}{c}\text { Risk-Based } \\
\text { Capital Ratio }\end{array}$ & $\begin{array}{l}\text { Risk-Weighted } \\
\text { Assets Ratio }\end{array}$ & $\begin{array}{l}\text { Risk-Based } \\
\text { Capital }\end{array}$ & $\begin{array}{l}\text { Risk-Weighted } \\
\text { Assets }\end{array}$ & $\mathrm{ROA}$ & $\sigma \mathrm{ROA}$ & $\begin{array}{c}\text { Non- } \\
\text { Performing } \\
\text { Loans Ratio }\end{array}$ & $\begin{array}{l}\text { Liquidity } \\
\text { Ratio }\end{array}$ \\
\hline Class 1 Enforcement Action & $\begin{array}{c}0.091 * * * \\
(7.53)\end{array}$ & $\begin{array}{c}-0.029 * * * \\
(-2.68)\end{array}$ & $\begin{array}{l}-0.049^{*} \\
(-1.74)\end{array}$ & $\begin{array}{c}-0.112 * * * \\
(-3.51)\end{array}$ & $\begin{array}{c}0.009 * * \\
(2.13)\end{array}$ & $\begin{array}{c}0.005^{* * * *} \\
(3.64)\end{array}$ & $\begin{array}{c}-0.019 * * * \\
(-7.30)\end{array}$ & $\begin{array}{l}0.012 \\
(1.62)\end{array}$ \\
\hline \multicolumn{9}{|c|}{ First-Stage } \\
\hline Gender of Supervisor's Bank Examiners & $\begin{array}{c}1.301 * * * \\
(4.79)\end{array}$ & $\begin{array}{c}1.301 * * * \\
(4.79)\end{array}$ & $\begin{array}{c}1.298 * * * \\
(4.78)\end{array}$ & $\begin{array}{c}1.390 * * * \\
(5.15)\end{array}$ & $\begin{array}{c}1.301 * * * \\
(4.79)\end{array}$ & $\begin{array}{c}1.301 * * * \\
(4.79)\end{array}$ & $\begin{array}{c}1.285 * * * \\
(4.72)\end{array}$ & $\begin{array}{c}1.301 * * * \\
(4.79)\end{array}$ \\
\hline Observations & 157,956 & 157,951 & 157,931 & 157,951 & 157,959 & 157,959 & 157,832 & 157,960 \\
\hline
\end{tabular}




\section{Table X}

\section{Endogeneity of the Timing of the Class 1 Enforcement Actions on the Intensive Margin}

The table reports coefficient estimates and z-statistics (in parentheses) of a three-stage model. Capital Quarter Fall is a cardinal variable that takes the value of the number of consecutive quarters that the risk-based capital ratio is falling relative to its value in the previous quarter and zero otherwise. In the first stage (Panel A), we estimate a zero-inflated Poisson model for Equation (1). In Panel B, we estimate Equation (2) using a simple 2SLS estimator, where the endogenous Capital Quarter Fall is instrumented with the fitted values from the zero-inflated Poisson model. For expositional brevity only the results on the variables of interest are presented in Panels A and B. Definitions for all variables are provided in Table I. The dependent variables of each regression are noted in the first line of the table below. The ***, **, and * marks denote statistical significance at the 1, 5, and 10\% level, respectively.

\section{Panel A. Zero-Inflated Poisson Model for Equation (1)}

\begin{tabular}{lcc} 
& Poisson & Zero-Inflated Part \\
\hline Dependent variable & Capital Quarter Fall \\
\hline Gender of Supervisor's Bank Examiners & $-2.718^{* *}$ & \\
& $(-2.40)$ & $53.481^{* * *}$ \\
Risk-Based Capital Ratio & $-3.895^{* * *}$ & $(8.19)$ \\
\hline Obs. & $(-3.93)$ & 858 \\
Nonzero Obs. & 315 \\
Zero Obs. & 543 \\
McFadden's Adjusted-Rsq & 0.110 \\
Log-Likelihood Full Model & -1081.305 \\
Vuong Test: Zip vs. Standard Poisson & $5.48^{* * *}$ \\
\hline \hline
\end{tabular}

Panel B. 2SLS Estimation of Equation (2)

\begin{tabular}{|c|c|c|c|c|}
\hline $\begin{array}{l}\text { Dependent Variable (Change from } t \text { to } \\
t+4) \text { : }\end{array}$ & $\begin{array}{c}\text { I } \\
\text { Risk-Based } \\
\text { Capital Ratio }\end{array}$ & $\begin{array}{c}\text { II } \\
\text { Risk-Weighted } \\
\text { Assets Ratio } \\
\end{array}$ & $\begin{array}{c}\text { III } \\
\text { Risk-Based } \\
\text { Capital } \\
\end{array}$ & $\begin{array}{c}\text { IV } \\
\text { Risk-Weighted } \\
\text { Assets } \\
\end{array}$ \\
\hline Capital Quarter Fall & $\begin{array}{c}-0.002 * * * \\
(-4.47)\end{array}$ & $\begin{array}{l}-0.001 \\
(-1.28)\end{array}$ & $\begin{array}{c}-0.031 * * * \\
(-5.35)\end{array}$ & $\begin{array}{l}0.001 \\
(0.45)\end{array}$ \\
\hline \multicolumn{5}{|l|}{ Diagnostics } \\
\hline $\begin{array}{l}\text { Kleibergen-Paap rk LM stat. } \\
\text { (underidentification test) }\end{array}$ & $196.10 * * *$ & $196.10^{* * *}$ & $196.10 * * *$ & $196.10 * * *$ \\
\hline $\begin{array}{l}\text { Kleibergen-Paap rk Wald F stat. } \\
\text { (weak identification test) }\end{array}$ & $397.69 * * *$ & $397.69 * * *$ & $397.69 * * *$ & $397.69 * * *$ \\
\hline Obs. & 783 & 783 & 783 & 783 \\
\hline \multicolumn{5}{|c|}{ First Stage of the 2SLS: Dependent Variable is Capital Quarter Fall } \\
\hline $\begin{array}{l}\text { Fitted Values from } \\
\text { Zero-Inflated Poisson Model } \\
\text { F-test for excluded instrument }\end{array}$ & $\begin{array}{l}5.540 * * * \\
(19.94) \\
397.69 * * *\end{array}$ & $\begin{array}{l}5.540 * * * \\
(19.94) \\
397.69 * * *\end{array}$ & $\begin{array}{l}5.540 * * * \\
(19.94) \\
397.69 * * *\end{array}$ & $\begin{array}{l}5.540 * * * \\
(19.94) \\
397.69 * * *\end{array}$ \\
\hline
\end{tabular}




\section{Table XI}

Impact of Relatively Late Enactment of the Class 1 Enforcement Actions on the Probability of Liquidation or Failure

The table reports coefficient estimates and t-statistics (in parentheses) of the two-stage treatment effects model of equations (1) and (2), where the dependent variable in the second stage regression is Inactive or Inactive One Year. Inactive is a dummy variable that takes the value of 1 for the eight quarters before the effective quarter a bank is liquidated or failed, and zero otherwise. Inactive One Year is a dummy variable that takes the value of 1 for the four quarters before the effective quarter a bank is liquidated or failed, and zero otherwise. We use the Class 1 enforcement actions and a clean $(-4,+4)$ quarters event window. For expositional brevity only the results on the variables of interest are presented. Definitions for all variables are provided in Table I. The dependent variables of each regression are noted in the first line of the table below. The $* * *, * *$, and $*$ marks denote statistical significance at the 1,5 , and $10 \%$ level, respectively

\begin{tabular}{|c|c|c|}
\hline \multicolumn{3}{|c|}{ Panel A: Full sample } \\
\hline Dependent Variable: & $\begin{array}{c}\text { I } \\
\text { Inactive }\end{array}$ & $\begin{array}{l}\text { II } \\
\text { Inactive } \\
\text { One Year }\end{array}$ \\
\hline Class 1 Enforcement Action & $\begin{array}{c}0.434 * * * \\
(39.64)\end{array}$ & $\begin{array}{c}0.293 * * * \\
(37.98)\end{array}$ \\
\hline Gender of Supervisor's Bank Examiners & $\begin{array}{c}1.075^{* * * *} \\
(4.70) \\
\end{array}$ & $\begin{array}{c}1.075^{* * *} \\
(4.70)\end{array}$ \\
\hline Observations & 295,934 & 295,934 \\
\hline \multicolumn{3}{|c|}{$\begin{array}{l}\text { Panel B: } \\
\frac{\text { Including Only Bank-Quarters during which the Capital Quarter Fall }}{\text { and the Risk-Weighted Assets Quarter Rise is less than two }}\end{array}$} \\
\hline Class 1 Enforcement Action & $\begin{array}{c}0.253 * * * \\
(24.81)\end{array}$ & $\begin{array}{c}0.144 * * * \\
(22.69)\end{array}$ \\
\hline \multicolumn{3}{|c|}{$\underline{\text { First Stage }}$} \\
\hline Gender of Supervisor's Bank Examiners & $\begin{array}{c}0.936 * * * \\
(3.53)\end{array}$ & $\begin{array}{c}0.936 * * * \\
(3.53)\end{array}$ \\
\hline Observations & 180,858 & 180,858 \\
\hline
\end{tabular}


Figure I

Responses of the Bank Ratios Before and After the Enactment of the Class 1 Enforcement Actions

$t=0$ is the quarter that the enforcement action becomes effective (i.e., it is signed)
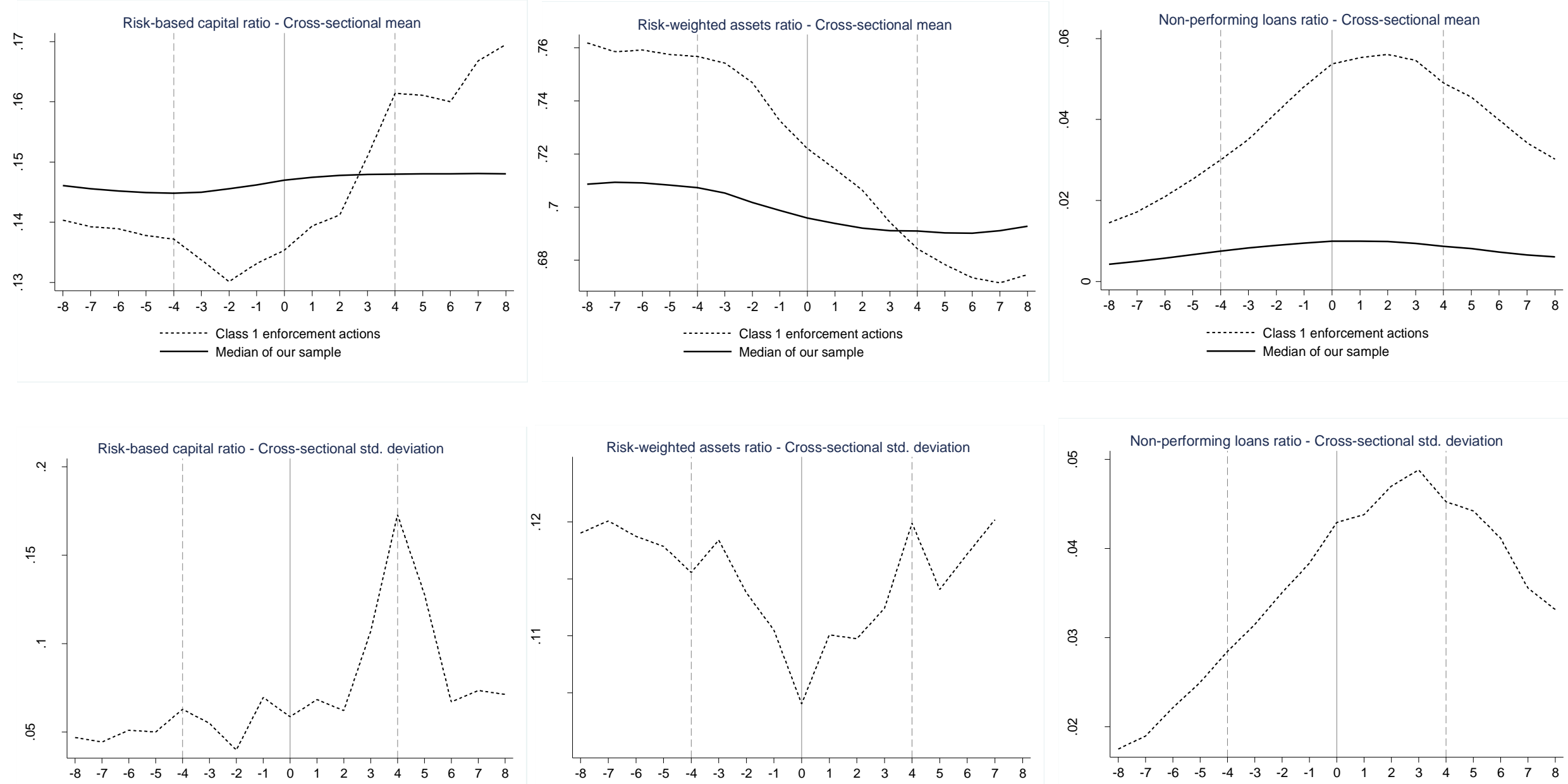
Figure II

Responses of the Bank Ratios Before and After the Enactment of the Class 1 Enforcement Actions in the Pre-Crisis Period $t=0$ is the quarter that the enforcement action becomes effective (i.e., it is signed)
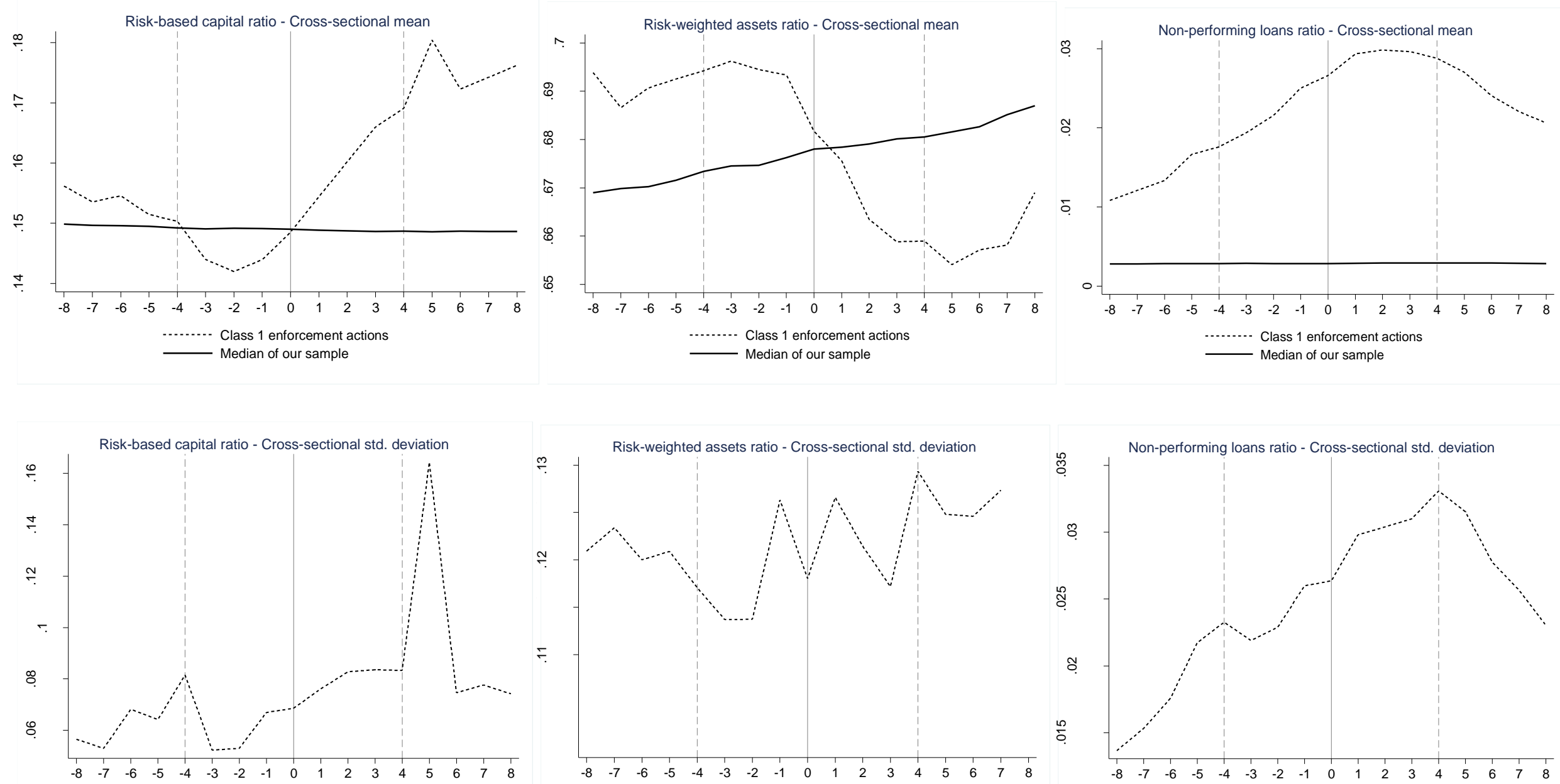


\section{Figure III}

Responses of the Bank Ratios Before and After the Enactment of the Class 1 Enforcement Actions in the Post-Crisis Period $t=0$ is the quarter that the enforcement action becomes effective (i.e., it is signed)
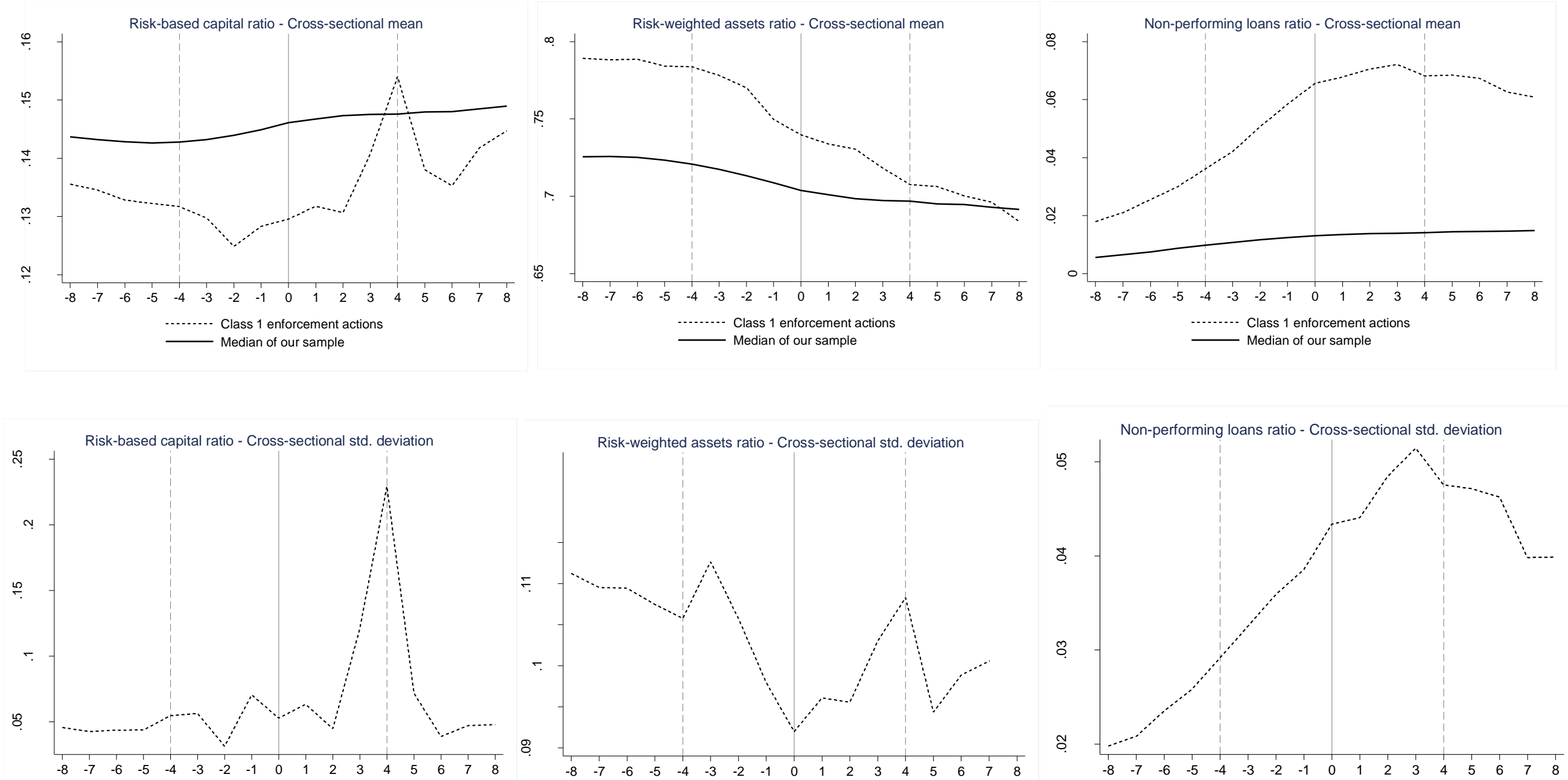
Table A.I

Classification of formal enforcement actions on a one-by-one basis

\begin{tabular}{|c|c|c|}
\hline $\begin{array}{c}\text { Relevance for } \\
\text { banks' safety and } \\
\text { soundness }\end{array}$ & Class & Reasons \\
\hline & 1 & $\begin{array}{r}\text { Capital adequacy and liquidity, asset quality, provisions and } \\
\text { reserves, large exposures and exposures to related parties }\end{array}$ \\
\cline { 2 - 3 } & 2 & $\begin{array}{r}\text { Internal control and audit systems, money laundering, bank } \\
\text { secrecy, consumer protection and foreign assets control }\end{array}$ \\
\cline { 2 - 3 } & 3 & $\begin{array}{r}\text { Breaches of the requirements concerning the fitness and propriety } \\
\text { of banks' board members and senior management, as well as other } \\
\text { persons closely associated with banks (institution affiliated parties) }\end{array}$ \\
\cline { 2 - 3 } & 4 & $\begin{array}{r}\text { Typical infringements of specific laws } \\
\text { (e.g., Home Mortgage Disclosure Act, Flood Insurance Act, Flood } \\
\text { Disaster Protection Act, etc) }\end{array}$ \\
\hline
\end{tabular}

The categorization of formal enforcement actions in classes reflects the internal taxonomy of the so-called "prudential requirements" as set out in the Basel Committee Core Principles for Effective Banking Supervision (Basel, 2012). The first set of principles basically covers the field of capital adequacy, asset quality, loss provisions and reserves, large exposures and exposures to related parties (Principles 16, 18-20), thus corresponding to the scope of Class 1 actions. A second group of principles on the robustness of internal organization procedures pertains to internal control and audit systems as well to management information and risk management arrangements (Principles 14-15, 26), thus mirroring the ambit of Class 2 actions. Formal enforcement actions against board members, senior management and persons closely connected with the bank (institution-affiliated parties) comprise the Class 3 actions, mainly covering instances of professional incompetence, fraud and insider abuse. Notice, however, that the association of such enforcement actions with financial safety and soundness is relatively weak, for several reasons: (a) supervisors are heavily oriented towards addressing concerns regarding the safety and soundness of ailing banks per se ("institutional enforcement") and, as a consequence, they give the greatest priority to Class 1 (and Class 2 actions) rather than to actions against individuals or other institution-affiliated parties; (b) investigation and successful prosecution of fraud and insider abuse cases is extremely complex and time consuming (e.g., involves massive and complicated transactions, records may be poor or even nonexistent, the effect of white-collar crimes may appear with substantial delays) which also undermines the effectiveness of the relevant actions regarding financial safety and soundness, (c) internal organization inefficiencies lie behind the development of fraud, insider abuse, or even incompetence, hence enforcement actions against institution-affiliated parties are likely to be already captured by the Class 2 formal enforcement actions arguments (Brunmeier and Willardson, 2006; GAO, 1989/4). Finally, a fourth class of formal enforcement actions could be contemplated as a "residual category" (e.g., actions for typical infringements of laws, including, Home Mortgage Disclosure Act and Flood Insurance Act). Evidently, the particular class would encompass actions with considerably heterogeneous underlying cause and would be even more remotely related to financial safety and soundness of banks. 
Table A.II

Construction of the instrumental variable

Dependent variable is the Original Gender of Supervisor's Bank Examiners

\begin{tabular}{lcc} 
& FDIC & OCC \\
\hline Trend 2000Q1-2009Q1 & $0.000^{* * * *}$ & $0.000^{* * *}$ \\
& $(4.85)$ & $(2.88)$ \\
Constant & $0.316^{* * *}$ & $0.358^{* * *}$ \\
& $(201.55)$ & $(119.90)$ \\
\hline Diagnostics & & \\
\hline R-sq. within & 0.010 & 0.004 \\
R-sq. between & 0.200 & 0.008 \\
R-sq. overall & 0.003 & 0.000 \\
Sigma_u & 0.107 & 0.121 \\
Sigma_e & 0.051 & 0.090 \\
Observations & 2,296 & 2,011 \\
No of cross-sections (states) & 45 & 41 \\
\hline
\end{tabular}

Figure A.I

Original Gender of Supervisor's Bank Examiners - Average Across States

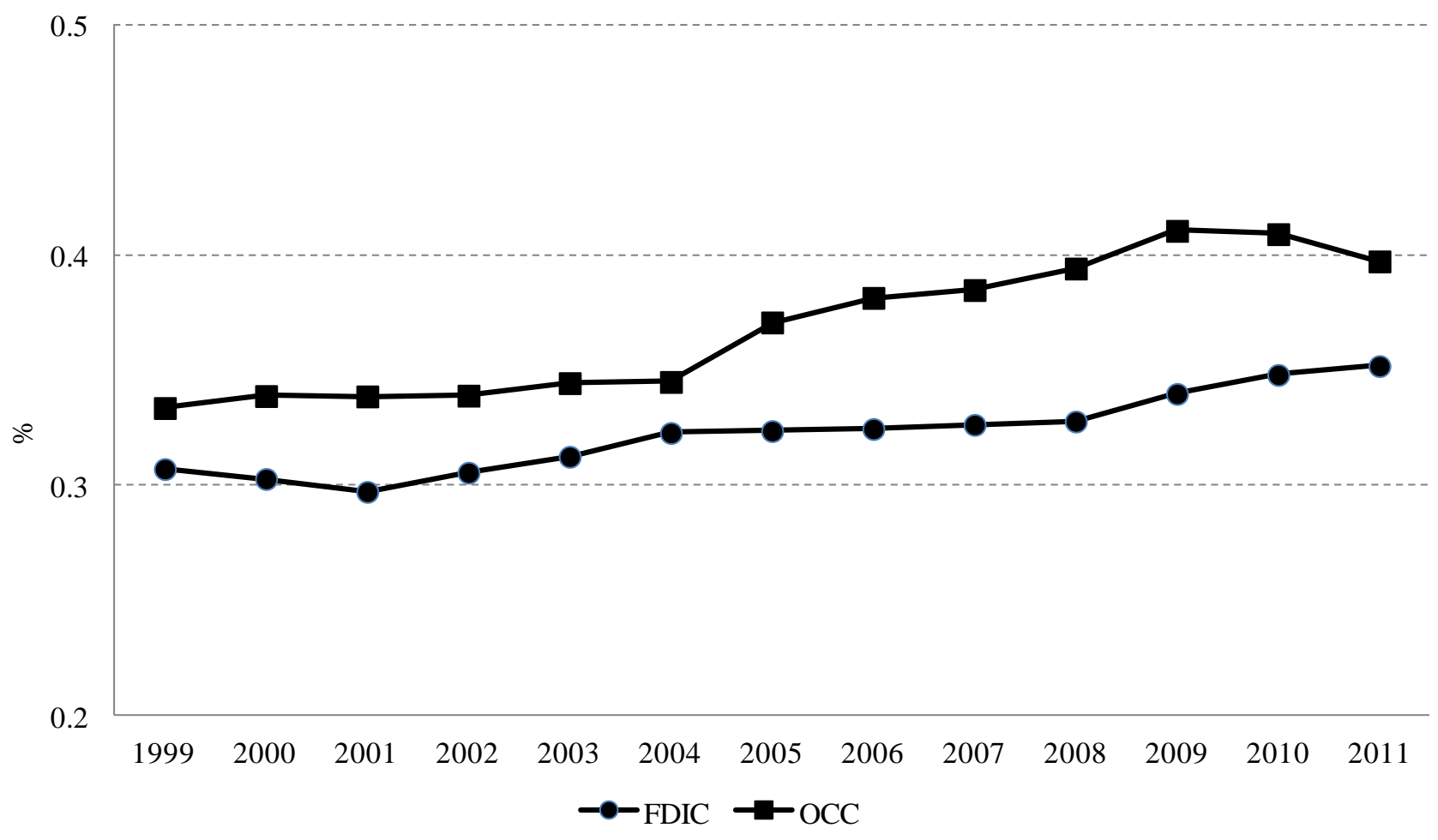


Table A.III

Summary Statistics - Original Gender of Supervisor's Bank Examiners per State and Supervisor

The table reports descriptive statistics for the yearly averages of the Original Gender of Supervisor's Bank Examiners, i.e., the share of female bank examiners, per state for the FDIC and the OCC. Data are obtained from the FedScope Employment Cube, which are available online from the Office of Personnel Management. Sample period is 2000-2010.

\begin{tabular}{|c|c|c|c|c|c|c|c|c|c|c|}
\hline \multirow[b]{2}{*}{ State } & \multicolumn{5}{|c|}{ FDIC } & \multicolumn{5}{|c|}{$\mathrm{OCC}$} \\
\hline & Obs. & Mean & St. Dev. & Min. & Max. & Obs. & Mean & St. Dev. & Min. & Max. \\
\hline $\mathrm{AL}$ & 11 & 0.406 & 0.038 & 0.357 & 0.480 & 11 & 0.336 & 0.146 & 0.111 & 0.572 \\
\hline AR & 11 & 0.294 & 0.027 & 0.250 & 0.348 & 11 & 0.393 & 0.049 & 0.308 & 0.474 \\
\hline $\mathrm{AZ}$ & 11 & 0.403 & 0.039 & 0.340 & 0.460 & 11 & 0.351 & 0.065 & 0.267 & 0.467 \\
\hline $\mathrm{CA}$ & 11 & 0.376 & 0.033 & 0.310 & 0.418 & 11 & 0.309 & 0.034 & 0.263 & 0.355 \\
\hline $\mathrm{CO}$ & 11 & 0.218 & 0.027 & 0.182 & 0.254 & 11 & 0.396 & 0.066 & 0.286 & 0.455 \\
\hline $\mathrm{CT}$ & 11 & 0.569 & 0.032 & 0.517 & 0.625 & - & & & & \\
\hline $\mathrm{DC}$ & 11 & 0.368 & 0.049 & 0.284 & 0.426 & 11 & 0.417 & 0.024 & 0.376 & 0.455 \\
\hline DE & 11 & 0.442 & 0.102 & 0.300 & 0.611 & 8 & 0.236 & 0.103 & 0.100 & 0.333 \\
\hline FL & 11 & 0.286 & 0.040 & 0.231 & 0.338 & 11 & 0.341 & 0.031 & 0.293 & 0.393 \\
\hline GA & 11 & 0.340 & 0.020 & 0.305 & 0.365 & 11 & 0.437 & 0.061 & 0.350 & 0.526 \\
\hline $\mathrm{HI}$ & 2 & 0.000 & 0.000 & 0.000 & 0.000 & - & & & & \\
\hline IA & 11 & 0.299 & 0.024 & 0.269 & 0.338 & 11 & 0.270 & 0.130 & 0.000 & 0.429 \\
\hline IL & 11 & 0.392 & 0.020 & 0.365 & 0.423 & 11 & 0.407 & 0.024 & 0.375 & 0.447 \\
\hline IN & 11 & 0.283 & 0.015 & 0.263 & 0.307 & 11 & 0.411 & 0.050 & 0.333 & 0.480 \\
\hline $\mathrm{KS}$ & 11 & 0.376 & 0.047 & 0.299 & 0.431 & 11 & 0.422 & 0.055 & 0.344 & 0.515 \\
\hline KY & 11 & 0.258 & 0.048 & 0.176 & 0.327 & 11 & 0.311 & 0.048 & 0.263 & 0.380 \\
\hline LA & 11 & 0.342 & 0.016 & 0.311 & 0.364 & 11 & 0.320 & 0.060 & 0.231 & 0.429 \\
\hline MA & 11 & 0.395 & 0.027 & 0.366 & 0.438 & 11 & 0.459 & 0.107 & 0.311 & 0.581 \\
\hline MD & 11 & 0.468 & 0.121 & 0.300 & 0.637 & 2 & 0.417 & 0.118 & 0.333 & 0.500 \\
\hline $\mathrm{ME}$ & - & & & & & 9 & 0.000 & 0.000 & 0.000 & 0.000 \\
\hline MI & 11 & 0.423 & 0.050 & 0.353 & 0.505 & 11 & 0.234 & 0.044 & 0.157 & 0.300 \\
\hline $\mathrm{MN}$ & 11 & 0.281 & 0.033 & 0.238 & 0.344 & 11 & 0.381 & 0.039 & 0.329 & 0.432 \\
\hline MO & 11 & 0.282 & 0.016 & 0.258 & 0.315 & 11 & 0.392 & 0.039 & 0.333 & 0.455 \\
\hline MS & 11 & 0.285 & 0.060 & 0.172 & 0.360 & 11 & 0.253 & 0.031 & 0.200 & 0.333 \\
\hline MT & 11 & 0.152 & 0.050 & 0.076 & 0.214 & 11 & 0.766 & 0.070 & 0.583 & 0.833 \\
\hline $\mathrm{NC}$ & 11 & 0.266 & 0.031 & 0.208 & 0.316 & 11 & 0.337 & 0.023 & 0.309 & 0.382 \\
\hline ND & 11 & 0.322 & 0.034 & 0.263 & 0.392 & 11 & 0.239 & 0.095 & 0.111 & 0.385 \\
\hline $\mathrm{NE}$ & 11 & 0.274 & 0.043 & 0.222 & 0.342 & 11 & 0.443 & 0.048 & 0.378 & 0.515 \\
\hline NH & 11 & 0.218 & 0.026 & 0.182 & 0.265 & - & & & & \\
\hline NJ & 11 & 0.381 & 0.042 & 0.318 & 0.455 & 11 & 0.240 & 0.234 & 0.000 & 0.491 \\
\hline NM & 11 & 0.164 & 0.051 & 0.106 & 0.235 & 11 & 0.682 & 0.132 & 0.484 & 0.833 \\
\hline NY & 11 & 0.282 & 0.048 & 0.214 & 0.360 & 11 & 0.376 & 0.016 & 0.352 & 0.398 \\
\hline $\mathrm{OH}$ & 11 & 0.215 & 0.050 & 0.148 & 0.313 & 11 & 0.350 & 0.072 & 0.253 & 0.443 \\
\hline OK & 11 & 0.229 & 0.053 & 0.176 & 0.309 & 11 & 0.209 & 0.023 & 0.173 & 0.250 \\
\hline OR & 11 & 0.109 & 0.046 & 0.059 & 0.199 & - & & & & \\
\hline PA & 11 & 0.414 & 0.015 & 0.390 & 0.440 & 11 & 0.355 & 0.010 & 0.333 & 0.370 \\
\hline PR & 11 & 0.530 & 0.110 & 0.333 & 0.667 & - & & & & \\
\hline RI & - & & & & & 3 & 0.397 & 0.108 & 0.298 & 0.513 \\
\hline $\mathrm{SC}$ & 11 & 0.498 & 0.051 & 0.385 & 0.550 & - & & & & \\
\hline SD & 11 & 0.365 & 0.040 & 0.292 & 0.414 & 11 & 0.452 & 0.083 & 0.364 & 0.583 \\
\hline $\mathrm{TN}$ & 11 & 0.359 & 0.038 & 0.298 & 0.417 & 11 & 0.332 & 0.031 & 0.289 & 0.388 \\
\hline TX & 11 & 0.279 & 0.024 & 0.250 & 0.323 & 11 & 0.372 & 0.029 & 0.333 & 0.421 \\
\hline UT & 11 & 0.159 & 0.033 & 0.105 & 0.205 & 11 & 0.330 & 0.077 & 0.235 & 0.454 \\
\hline VA & 11 & 0.216 & 0.110 & 0.100 & 0.418 & 11 & 0.444 & 0.058 & 0.368 & 0.520 \\
\hline WA & 11 & 0.316 & 0.046 & 0.227 & 0.365 & 11 & 0.407 & 0.332 & 0.000 & 1.000 \\
\hline WI & 11 & 0.348 & 0.031 & 0.313 & 0.387 & 11 & 0.513 & 0.065 & 0.360 & 0.588 \\
\hline WV & 11 & 0.281 & 0.054 & 0.180 & 0.333 & 11 & 0.190 & 0.062 & 0.125 & 0.308 \\
\hline
\end{tabular}


Table A.IV

State Socioeconomic Variables and Correlations with the Gender of Supervisor's Bank Examiners

Panel A reports descriptive statistics for socioeconomic variables at the state-year level. Panel B reports correlations between the state socioeconomic and bank variables as well as between the Original Gender of Supervisor's Bank Examiners and the instrument employed in the analysis. Variables' definitions and their sources in parentheses are: (log) per capita income is the natural logarithm of per capita income at the state-year level (U.S. Bureau of Economic Analysis); GDP growth rate (y-o-y) (U.S. Bureau of Economic Analysis); unemployment rate (U.S. Bureau of Labor Statistics); total bankruptcies is the natural logarithm of total business and personal bankruptcies (the Administrative Office of the U.S. Courts); share of white population (U.S. Census Bureau); and the share of college enrolment (National Center for Education Statistics). The bank variables in Panel B are state-year averages separately for the FDIC and the OCC supervised banks in each state (for bank variables definitions, see Table I). Sample period is $2000-2010$.

Panel A: Descriptive Statistics for State Socioeconomic Variables

\begin{tabular}{|c|c|c|c|c|c|}
\hline Variable & Obs. & Mean & St. Dev. & Min. & Max. \\
\hline (log) Per Capita Income & 487 & 10.446 & 0.197 & 9.978 & 11.158 \\
\hline GDP Growth Rate (y-o-y) & 487 & 1.792 & 2.614 & -8.300 & 12.700 \\
\hline Unemployment Rate & 487 & 5.617 & 1.982 & 2.200 & 13.300 \\
\hline Total Bankruptcies & 487 & 8.408 & 1.139 & 4.922 & 11.082 \\
\hline Share of White Population & 487 & 0.812 & 0.118 & 0.260 & 0.971 \\
\hline Share of College Enrolment & 487 & 0.063 & 0.021 & 0.040 & 0.231 \\
\hline
\end{tabular}

Panel B. Correlations Between the Gender of Supervisor's Bank Examiners and State and Bank Characteristics

\begin{tabular}{|c|c|c|c|c|}
\hline Variable & $\begin{array}{l}\text { Original Gender of } \\
\text { Supervisor's Bank } \\
\text { Examiners-FDIC }\end{array}$ & $\begin{array}{c}\text { Gender of } \\
\text { Supervisor's Bank } \\
\text { Examiners - FDIC }\end{array}$ & $\begin{array}{l}\text { Original Gender of } \\
\text { Supervisor's Bank } \\
\text { Examiners -OCC }\end{array}$ & $\begin{array}{c}\text { Gender of } \\
\text { Supervisor's Bank } \\
\text { Examiners - OCC }\end{array}$ \\
\hline $\begin{array}{l}\text { Original Gender of Supervisor's Bank } \\
\text { Examiners - FDIC }\end{array}$ & 1.000 & & & \\
\hline $\begin{array}{l}\text { Gender of Supervisor's Bank Examiners - } \\
\text { FDIC }\end{array}$ & 0.478 & 1.000 & & \\
\hline $\begin{array}{l}\text { Original Gender of Supervisor's Bank } \\
\text { Examiners -OCC }\end{array}$ & -0.183 & 0.080 & 1.000 & \\
\hline $\begin{array}{l}\text { Gender of Supervisor's Bank Examiners - } \\
\text { OCC }\end{array}$ & 0.049 & 0.168 & 0.627 & 1.000 \\
\hline (log) Per Capita Income & 0.376 & 0.181 & 0.127 & 0.135 \\
\hline GDP Growth Rate (y-o-y)r & -0.138 & -0.107 & -0.059 & -0.163 \\
\hline Unemployment Rate & 0.132 & 0.222 & 0.094 & 0.215 \\
\hline Total Bankruptcies & 0.039 & -0.035 & -0.075 & -0.020 \\
\hline Share of White Population & -0.245 & -0.039 & -0.009 & 0.006 \\
\hline Share of College Enrollment & 0.067 & 0.065 & 0.097 & 0.055 \\
\hline Risk-Based Capital Ratio - FDIC Banks & -0.020 & 0.075 & & \\
\hline Risk-Weighted Assets Ratio - FDIC Banks & -0.087 & 0.035 & & \\
\hline Non-Performing Loans Ratio - FDIC Banks & 0.154 & 0.252 & & \\
\hline ROA - FDIC Banks & -0.214 & -0.250 & & \\
\hline Liquidity Ratio - FDIC Banks & -0.170 & 0.018 & & \\
\hline Bank Size - FDIC Banks & 0.345 & 0.122 & & \\
\hline Risk-Based Capital Ratio - OCC Banks & & & -0.164 & 0.009 \\
\hline Risk-Weighted Assets Ratio - OCC Banks & & & 0.237 & 0.066 \\
\hline Non-Performing Loans Ratio - OCC Banks & & & 0.180 & 0.228 \\
\hline ROA - OCC Banks & & & -0.215 & -0.176 \\
\hline Liquidity Ratio - OCC Banks & & & 0.207 & 0.240 \\
\hline Bank Size - OCC Banks & & & -0.245 & 0.026 \\
\hline
\end{tabular}




\section{Appendix B.}

\section{Information on the matching of our instrumental variable to the banks in our sample}

The Washington office of the OCC is the main office and headquarters of the OCC. The OCC is divided into four geographic regions-districts. Each district office of the OCC is responsible for the direct supervision of national banks in its district, with the exception of large banks, which are supervised by the Washington office (on large banks, please see below). Field offices within these districts support the bank supervisory responsibilities of the district offices. The list of the OCC's field offices and their location is available at http://www.occ.gov/about/who-we-are/district-and-field-offices/index-organization.html. Although the OCC's headquarters set the policy and direction and oversee bank supervision, on-site examinations are decentralized, in the sense that they are conducted via the OCC's field offices located in cities throughout the US. The principle is that on-site examinations of banks are allocated to the examiners of that particular OCC field office located at the state where the banks are headquartered.

National banks in states that do not have an OCC field or district office ("remote national banks") are supervised on the basis of proximity from nearby offices. Though the OCC kindly offered us some indicative examples of how supervision of those "remote national banks" is allocated, we did not have information covering all remote national banks and making own calculations on supervisory proximity would be extremely ambiguous and arbitrary. Precisely because we did not feel absolutely confident on how exactly to assign responsibility for on-site examinations of those "remote national banks", we decided not to include them in our sample.

Moreover, banks with assets more than $\$ 50$ billion (large banks) are supervised by the OCC's Large Bank Supervision Division in Washington, in the sense that exam teams are allocated to and work on-site. This "idiosyncrasy" of the on-site audits of the large banks led us to leave large banks out from the sample (i.e., 33 banks), because we did not feel absolutely confident as to how best to apply our instrument to these on-site exam teams that are appointed by the OCC headquarters. If we postulate that the OCC Washington headquarters is the responsible office for the on-site examination of large banks, our results remain unaffected.

The organizational pillars of the FDIC supervision and examination system resemble the ones of the OCC, in the sense that the banks which fall under the supervisory umbrella of the FDIC (operating as a primary supervisor) are assigned to supervisory regional offices, which oversee and coordinate the supervisory program for each bank, while field offices are responsible for the on-site examination of banks. Fortunately, as far the 
FDIC is concerned, information on the specific field office that is responsible for the on-site examination for each individual bank (regardless of its size) can be derived from a publicly available source (https://www2.fdic.gov/idasp/main.asp). 